\title{
Recent Advances in Potential Nanoparticles and Nanotechnology for Sensing Food-Borne Pathogens and Their Toxins in Foods and Crops: Current Technologies and Limitations
}

\author{
Preeyaporn Koedrith, Thalisa Thasiphu, Kooranee Tuitemwong ${ }^{1}$, \\ Rattana Boonprasert* and Pravate Tuitemwong1,*** \\ Faculty of Environment and Resource Studies, Mahidol University, \\ 999 Phuttamonthon 4 Road, Phuttamonthon District, Nakhon Pathom 73170, Thailand \\ ${ }^{1}$ Food Safety Center, Institute for Scientific and Technological Research and Services (ISTRS), \\ King Mongkut's University of Technology Thonburi (KMUTT), Bangkok 10140, Thailand
}

(Received January 20, 2014; accepted September 5, 2014)

Key words: biosensors, fluorescent nanoparticles, food-borne pathogens, nanotechnology, rapid detection

Food-borne pathogens cause infectious diseases in people worldwide. Hence, the development of rapid detection methods for food-borne pathogens is necessary. The application of potentially useful nanoparticles (NPs) results in enhanced sensitivity, improved response time, and increased portability owing to their distinct chemical and optical features. The widely used NPs include quantum dot (QD) NPs, metal NPs, silica NPs, and magnetic NPs as well as potent intrinsic antimicrobial NPs. The NPs can also act as multivalent scaffolds for supramolecular assemblies since their high surface-tovolume ratio enables the functionalization of unique spatial domains, allowing their versatile implementation in various sensing schemes. In this review, we focus on the developments and analytical applications of NPs in chemical and biological sensing within foods and crop matrices. We also discuss advanced tools of NP-based sensitive assays, key requirements, and shortcomings.

\section{Introduction}

Food-borne diseases are a public health threat with increasing socio-ecomonic costs. In the United States, it has been estimated that 31 main food-borne pathogens

*Corresponding author: e-mail: rattana.boo@mahidol.ac.th

${ }^{* *}$ Corresponding author: e-mail: pravate.tui@kmutt.ac.th 
cause over 9 million cases of illnesses and over 1000 deaths. ${ }^{(1)}$ The cost of managing these problems is over $\$ 70$ billion annually. ${ }^{(2)}$ For protection against such preventable diseases, federal agencies such as the US Department of Agriculture (USDA), Food and Drug Administration (FDA), and Environmental Protection Agency (EPA) are responsible for adopting effective monitoring technologies and systems globally.

Most of the food-borne diseases are caused by microorganisms such as bacteria, viruses, and parasites. Gastrointestinal symptoms such as diarrhea, abdominal pain, nausea, and vomiting are commonly associated with microbial infections. For instance, infections by Cryptosporidium sp., Entamoeba histolytica, Escherichia. coli, Salmonella sp., Shigella sp., and Vibrio cholerae result in diarrhea as the major clinical symptom. Hence, food-borne pathogens are of utmost concern in food safety. Table 1 summarizes the major types of microorganism responsible for food-borne diseases in the United States. ${ }^{(3)}$

Table 1

Major types of microorganism causing food-borne diseases in the United States.

\begin{tabular}{|c|c|c|c|c|}
\hline Bacteria & & & Viruses & Parasites \\
\hline Bacillus cereus & $\begin{array}{l}\text { Listeria } \\
\text { monocytogenes }\end{array}$ & $\begin{array}{l}\text { Staphylococcus } \\
\text { aureus }\end{array}$ & Astrovirus & $\begin{array}{l}\text { Cryptosporidium } \\
\text { parvum }\end{array}$ \\
\hline Bacillus anthracis & $\begin{array}{l}\text { Mycobacterium } \\
\text { avium }\end{array}$ & Vibrio cholerae & Enterovirus & $\begin{array}{l}\text { Cyclospora } \\
\text { cayetanensis }\end{array}$ \\
\hline Brucella sp. & $\begin{array}{l}\text { Mycobacterium } \\
\text { bovis }\end{array}$ & $\begin{array}{l}\text { Vibrio } \\
\text { parahaemolyticus }\end{array}$ & Hepatitis-A & Giardia intestinalis \\
\hline Campylobacter sp. & $\begin{array}{l}\text { Nontyphoidal } \\
\text { Salmonella sp. }\end{array}$ & Vibrio vulnificus & Hepatitis-E & Giardia lamblia \\
\hline $\begin{array}{l}\text { Clostridium } \\
\text { botulinum }\end{array}$ & $\begin{array}{l}\text { Salmonella } \\
\text { enterica serotype } \\
\text { Typhi }\end{array}$ & $\begin{array}{l}\text { Yersinia } \\
\text { enterocolitica }\end{array}$ & Norovirus & Taenia saginata \\
\hline $\begin{array}{l}\text { Clostridium } \\
\text { perfringens }\end{array}$ & Shigella sp. & $\begin{array}{l}\text { Yersinia } \\
\text { pseudotuberculosis }\end{array}$ & Rotavirus & Taenia solium \\
\hline E. coli $\mathrm{O} 157: \mathrm{H} 7$ & Streptococcus sp. & Yersinia pestis & & $\begin{array}{l}\text { Trichinella spiralis } \\
\text { Trichuris trichiura } \\
\text { Toxoplasma gondii }\end{array}$ \\
\hline
\end{tabular}

Top five food-borne pathogens resulting in the following:

\begin{tabular}{lll}
\hline Illness & Hospitalization & Death \\
\hline Norovirus & Nontyphoidal Salmonella sp. & Nontyphoidal Salmonella sp. \\
\hline Nontyphoidal Salmonella sp. & Norovirus & Toxoplasma gondii \\
\hline Clostridium perfringens & Campylobacter sp. & Listeria monocytogenes \\
\hline Campylobacter sp. & Toxoplasma gondii & Norovirus \\
\hline Staphylococcus aureus & E. coli O157 & Campylobacter $\mathrm{sp}$. \\
\hline
\end{tabular}


No global estimate is available on the prevalence of these food-borne diseases owing to their variety and extent. Food-borne diseases cannot be diagnosed precisely since several factors are involved in their etiology, and these diseases may only be manifested after long-term exposure. Thus, the actual number of cases is not obtained by public health authorities under surveillance programs. It has been estimated that 10 and $1 \%$ of food-borne diseases are not reported in developed and developing countries, respectively. ${ }^{(4)}$ Although the incidence of nonreporting of food-borne diseases is higher in developing countries, it is still considerably high in developed countries. ${ }^{(5)}$

Owing to food safety concerns as a global priority, standard methods have recently been developed for detecting and quantifying microorganisms in foods. Nevertheless, these methods are laborious and time-consuming with limited specificity and sensitivity. Currently, nanotechnology enables rapid detection and monitoring of pathogen and toxin contaminations at various steps in the food supply chain, thereby potentially reducing recalls and human health costs, especially those due to lethal foodborne diseases. When a contaminated sample is identified by rapid screening, standard microbiological techniques would still be required to confirm the presence of potential pathogens and/or toxins. Rapid, sensitive testing methods would also improve business efficiency in perishable-product-related food industries owing to the faster release of products without waiting for the results of a long, laborious test of its safety. Although only some types of food are withheld until results are available, sensors capable of detecting contaminated batches will enable the prompt removal of the contaminated raw materials or products from the food chain. Apart from investigative sampling, these rapid methods are also useful for verifying the efficacy of food safety systems such as Hazard Analysis and Critical Control Points (HACCP) and assuring the safety of end products.

In addition to the time delay between sampling and assay results, the aforementioned standard methods have disadvantages owing to a common deficiency: they rely on destructive sampling of food products rather than on-thefood nondestructive sampling. Nondestructive sampling-based safety testing prior to the food products leaving the farm or processing facility is a very powerful tool, particularly where homogenization is impractical. When pathogens are, however, distributed within foods (e.g., ground beef), there is no choice but only destructive testing. Even though the only way to verify that a food is $100 \%$ pathogen-free is to utilize the entire food for testing, this has been considered impractical.

Recently, molecular beacon (MB) technology, which utilizes organic fluorophores, has been developed for the detection and quantification of food-borne pathogens in vitro, ${ }^{(6-8)}$ in conjunction with quantitative polymerase chain reaction (qPCR). However, newer fluorescent structures, such as quantum dots (QDs), are attracting interest owing to their higher sensitivity and stability than other fluorophores and the possibility of simultaneous detection of multiple pathogens within a single sample. Numerous reviews have described the application of other nanoparticle-based biosensors (i.e., metallic and magnetic materials) for the detection and imaging of pathogens. ${ }^{(9-12)}$ In 
this review, we address the benefits of the molecular nanotechnologies using recently developed nanoparticles (i.e., QDs and metallic and magnetic nanoparticles) as emerging tools for protecting agricultural crops or the food supply chain from the farm to the consumer, their shortcomings, and strategies for further development of nano-biosensors.

\section{Current Techniques for Detecting Food-Borne Pathogens}

Detection of food-borne pathogens by conventional approaches usually involves microorganism identification by morphological evaluation through selective enrichment, biochemical analysis, and serological confirmation. ${ }^{(13)}$ Owing to these techniques being time-consuming, alternative methods based on different principles of detection have been developed (i.e., chromatography, flow cytometry, electrical conductance, impedance, infrared or fluorescence spectroscopy, and bioluminescence), which require highly qualified staff to operate the advanced complex equipment. ${ }^{(14)}$ The PCR technique that can repetitively amplify even a single strand of a specific nucleic acid target with definite length and sequence by using a thermostable DNA polymerase enables accurate determination, but target-DNA-specific primers need to be designed. ${ }^{(15,16)}$ With advancements in technologies, the cost-effective production of polyclonal antibodies gives rise to the commercialization of immunological detection techniques that enable the detection of various types of food-borne bacterium. ${ }^{(17)}$ Since nucleic acid-based detection is advantageous in terms of specificity, sensitivity, accuracy, speed, and capacity, novel methodologies using DNA chips have thus been established.(18-20) Under practical circumstances, they are difficult for the food industry and crop agriculture owing to their complexity. In addition to pathogen detection, the presence of drugs, flavoring agents, and pesticides at levels above the permitted standard levels needs to be investigated. ${ }^{(21)}$ An increasing need for a rapid, real-time, selective, and low-cost technique for the detection of biotic or abiotic contamination has led to advancements in biosensors. ${ }^{(2)}$

\section{Biosensors as Novel Potential Tools of Pathogen Detection Methods}

In principle, a biosensor is defined as an analytical device incorporating a biologically active material in intimate contact with an appropriate transduction element for the purpose of detecting and/or imaging any type of sample specimen (Fig. 1).(23) The types of biosensor depend on the method used for signal transduction (Fig. 1) such as optical, electrochemical, thermometric, and piezoelectric. ${ }^{(24,25)}$

\section{Nanoparticles in Biosensors for Food-Borne Pathogen Detection}

Potential biosensors using nanoparticles $(<100 \mathrm{~nm}$ in size $)$ have been developed without the need for cost-ineffective or complicated instruments, allowing the rapid detection of food-borne pathogens on a portable device. Their detection capacity can be improved using immuno-nanoparticles over conventional sensors. Example of potential nanoparticle biosensors for food-borne pathogens are shown in Table 2. For example, the sensitivity of a Salmonella. enteritidis-based impedimetric biosensor was improved by incorporating anti-Salmonella-antibody-conjugated nanoparticles. ${ }^{(26)}$ By coupling 


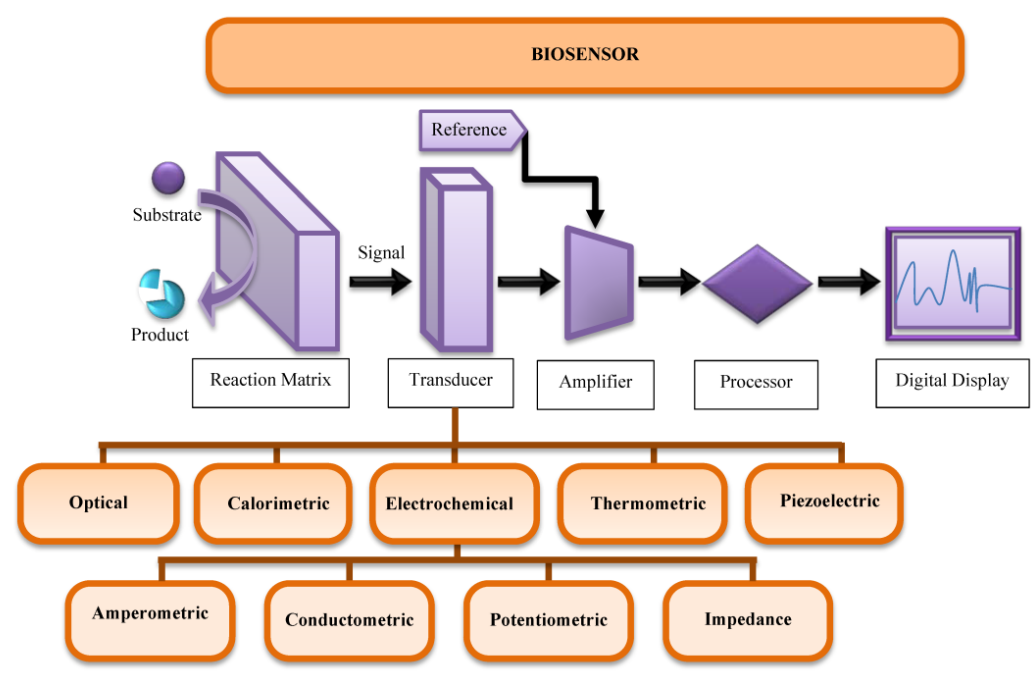

Fig. 1. (Color online) Scheme representing biosensor components consisting of different transducers depending on signal response type (i.e., optical, calorimetric, and electrochemical signals).

immuno-nanoparticles with enzymatic catalysis, an electrochemical immunosensor showed rapid and specific detection of pathogens. A screen-printed electrode coated with an agarose/nano-Au membrane and a horseradish peroxidase (HRP)-conjugated anti-Vibrio parahaemolyticus (HRP-anti-VP) antibody exhibited a detection limit of $7.4 \times 10^{4} \mathrm{CFU} / \mathrm{mL}$ against Vibrio parahaemolyticus. ${ }^{(27)}$ Combining immunomagnetic separation with enzymatic $p$-nitrophenyl phosphate hydrolysis by alkaline phosphatase (EC 3.1.3.1) could efficiently detect E. coli $\mathrm{O} 157: \mathrm{H} 7$ at levels as low as $10^{2} \mathrm{CFU} / \mathrm{mL}$ in a colorimetric assay based on the catalysis of "sandwich" structure complexes (antibodycoated micromagnetic beads- $E$. coli O157:H7-antibody-conjugated enzymes). ${ }^{(28)}$

Magnetic nanoparticles conjugated with an anti-E. coli antibody specific to $\mathrm{O}$ and $\mathrm{K}$ antigens were used to isolate E. coli $\mathrm{O} 157: \mathrm{H} 7$ from ground beef.(29) This research revealed that, owing to efficient diffusion and binding kinetics of nanoparticles, no mechanical mixing was required for immunomagnetic separation, suggesting their possible application in microfluidic devices.

Binding of a pathogenic bacterial cell with very fine nanoparticles can potentially alter their optical, physical and chemical properties, thereby facilitating the realtime detection of pathogens in accordance with the mode of signal transduction or amplification. Anti-E. coli-bound gold nanowire arrays (GNWAs) on an anodized porous alumina template were employed for capturing E. coli O157:H7.(30) The formation of a bacterial-cell-antibody complex alters the surface properties of the sensor (i.e., capacitance of biomembrane) by which the number of bound $E$. coli cells was estimated by electrochemical impedance spectroscopy (EIS). In this study, the GNWA biosensor was found to detect as few as ten E. coli cells in a sensor area of $0.173 \mathrm{~cm}^{2}$. 
Table 2

Important characteristics of potential biosensor-based detection assays using nanoparticles and strategies for biosensor developments for detection of food-borne pathogens including bacteria, viruses, as well as their toxins.

\begin{tabular}{|c|c|c|c|c|}
\hline Assay system/principle & Target of assay & Detection limit & $\begin{array}{l}\text { Assay } \\
\text { duration }\end{array}$ & Ref. \\
\hline \multicolumn{5}{|c|}{ 1. Various types of nanoparticle-based biosensor } \\
\hline $\begin{array}{l}\text { Nanoparticle-enhanced impedimetric } \\
\text { biosensors using antibodies } \\
\text { immobilized on interdigitated gold } \\
\text { electrodes }\end{array}$ & Salmonella enteritidis & $\begin{array}{l}10^{4} \mathrm{CFU} / \mathrm{mL} \text { in } \\
\mathrm{PBS} \text { and } 10^{5} \mathrm{CFU} / \mathrm{mL} \\
\text { in milk }\end{array}$ & $3 \mathrm{~min}$ & 26 \\
\hline $\begin{array}{l}\text { Disposable electrochemical } \\
\text { immunosensors based on screen-printed } \\
\text { electrode (SPE) coated with agarose/ } \\
\text { Nano-Au membrane and horseradish- } \\
\text { peroxidase-labeled antibody }\end{array}$ & Vibrio parahaemolyticus & $\begin{array}{l}7.374 \times 10^{4} \mathrm{CFU} / \mathrm{mL} \\
\text { in buffer solutions }\end{array}$ & $30 \mathrm{~min}$ & 27 \\
\hline $\begin{array}{l}\text { Mannose-encapsulated gold } \\
\text { nanoparticles (m-AuNP) based on } \\
\text { selective binding of m-AuNP to } \\
\text { mannose adhesin FimH of bacterial } \\
\text { type } 1 \text { pili }\end{array}$ & E. coli $\mathrm{O} 157: \mathrm{H} 7$ & Not indicated & Not indicated & 28 \\
\hline $\begin{array}{l}\text { Immunomagnetic separation with } \\
\text { magnetic nanoparticle-antibody } \\
\text { conjugates }\end{array}$ & E. coli $\mathrm{O} 157: \mathrm{H} 7$ & $\begin{array}{l}1.6 \times 10^{1} \mathrm{CFU} / \mathrm{mL} \text { without } \\
\text { any enrichment; } 8 \mathrm{CFU} / \\
\mathrm{mL} \text { with } 6 \mathrm{~h} \text { enrichment } \\
\text { from ground beef samples }\end{array}$ & $\begin{array}{l}15 \text { min; } \\
6 \mathrm{~h} \text { (with } \\
\text { enrichment) }\end{array}$ & 29 \\
\hline $\begin{array}{l}\text { Glycoconjugate-specific antibody- } \\
\text { bound gold nanowire arrays based on } \\
\text { enzyme-linked immunosorbent assay } \\
\text { (ELISA) }\end{array}$ & E. coli $\mathrm{O} 157: \mathrm{H} 7$ & Not indicated & Not indicated & 30 \\
\hline $\begin{array}{l}\text { Immunological bead-free cell detection } \\
\text { using QDs as reporter markers }\end{array}$ & $\begin{array}{l}\text { E. coli } \mathrm{O} 157: \mathrm{H} 7 \text { and } \\
\text { Salmonella sp. }\end{array}$ & $\begin{array}{l}\text { With } 24 \text { h enrichment, } 10 \\
\text { CFU/g from artificially } \\
\text { contaminated ground beef }\end{array}$ & $24 \mathrm{~h}$ & 32 \\
\hline $\begin{array}{l}\text { Rapid colorimetric gene sensing using } \\
\text { biomodification-free gold nanoparticles } \\
\text { based on polymerase chain reaction }\end{array}$ & $\begin{array}{l}\text { Listeria monocytogenes } \\
\text { and Salmonella enterica }\end{array}$ & $\begin{array}{l}0.015 \mathrm{ng} / \mathrm{mL} \text { and } 0.013 \\
\mathrm{ng} / \mathrm{mL} \text { genomic DNA of } \\
\text { L. monocytogenes and } S \text {. } \\
\text { enterica, respectively }\end{array}$ & $5 \mathrm{~min}$ & 33 \\
\hline $\begin{array}{l}\text { Antibody-conjugated Rubpy dye- } \\
\text { doped silica nanoparticles for } \\
\text { immunofluorescence microscopy } \\
\text { detection on glass slides }\end{array}$ & Vibrio cholerae $\mathrm{O} 1$ & $1 \mathrm{CFU} / \mathrm{mL}$ in buffer & $10 \mathrm{~min}$ & 34 \\
\hline $\begin{array}{l}\text { Antibody-conjugated fluorescent dye- } \\
\text { doped silica nanoparticles with glass } \\
\text { slide method under epifluorescence } \\
\text { microscope }\end{array}$ & E. coli $\mathrm{O} 157: \mathrm{H} 7$ & $1.6 \mathrm{CFU} / \mathrm{mL}$ in buffer & $60 \mathrm{~min}$ & 36 \\
\hline
\end{tabular}

2. Biosensor developments through nanoparticle-based signal enhancement using metallic nanoparticles, QDs, and nanomaterial complexes

Colorimetric assay with an antiSalmonella typhimurium $1 \times 10^{4} \mathrm{CFU} / \mathrm{mL}$ in buffer $5-10 \mathrm{~min}$ 40 salmonella antibody conjugated to oval-shaped gold nanoparticles for label-free detection 


\begin{tabular}{|c|c|c|c|c|}
\hline $\begin{array}{l}\text { Colorimetric detection of nucleic acid } \\
\text { signature of Shiga-toxin-producing } E \text {. } \\
\text { coli using gold nanoparticles }\end{array}$ & $\begin{array}{l}\text { Enterohemorrhagic } E . \\
\text { coli (EHEC) serotype } \\
\text { O157:H7 (stx2 an EHEC } \\
\text { signature) }\end{array}$ & $\begin{array}{l}1 \times 10^{6} \text { copies of target } \\
\text { DNA in buffer }\end{array}$ & Not indicated & 42 \\
\hline $\begin{array}{l}\text { Circulating-flow piezoelectric } \\
\text { biosensors based on gold nanoparticle } \\
\text { amplification and verification method } \\
\text { (DNA-based QCM sensor coupled with } \\
\text { PCR) }\end{array}$ & E. coli $\mathrm{O} 157: \mathrm{H} 7$ (eaeA) & $\begin{array}{l}1 \times 10^{2} \mathrm{CFU} / \mathrm{mL} \text { from } \\
\text { food samples (apple juice, } \\
\text { milk, and ground beef) }\end{array}$ & Not indicated & 43 \\
\hline $\begin{array}{l}\text { Ultrasensitive immunoassays based } \\
\text { on sandwich-type immunoreaction } \\
\text { with silver enhancement of nanogold } \\
\text { labels coupled with chemiluminescence } \\
\text { detection }\end{array}$ & S. typhimurium & $\begin{array}{l}5 \mathrm{CFU} / \mathrm{mL} \text { equivalent } \\
\text { target oligonucleotide } \\
\text { from actual food samples } \\
\text { (poultry \& products, pork } \\
\& \text { products, and ready-to- } \\
\text { eat food) }\end{array}$ & $30 \mathrm{~min}$ & 44 \\
\hline $\begin{array}{l}\text { Scanometric assays for on-slide } \\
\text { detection with dual enlargement of gold } \\
\text { nanoparticles }\end{array}$ & Campylobacter jejuni & $1 \mathrm{CFU} / \mathrm{mL}$ in buffer & About $2 \mathrm{~h}$ & 45 \\
\hline $\begin{array}{l}\text { SERS system with wavelet-based signal } \\
\text { processing and classification module }\end{array}$ & $\begin{array}{l}\text { Listeria spp. (including } L . \\
\text { monocytogenes) }\end{array}$ & Not indicated (in culture) & Within $24 \mathrm{~h}$ & 46 \\
\hline $\begin{array}{l}\text { SERS based silica-coated magnetic } \\
\text { nanoprobes }\end{array}$ & $\begin{array}{l}\text { Salmonella enterica } \\
\text { serovar Typhimurium and } \\
\text { Staphylococcus aureus }\end{array}$ & $\begin{array}{l}10^{3} \mathrm{CFU} / \mathrm{mL} \text { in spinach } \\
\text { solution and in peanut } \\
\text { butter }\end{array}$ & About $2 \mathrm{~h}$ & 48 \\
\hline $\begin{array}{l}\text { Fluorescence-based immunoassays } \\
\text { using QD-labeled antibodies }\end{array}$ & $\begin{array}{l}\text { L. monocytogenes [two } \\
\text { surface bound proteins, } \\
\text { Internalin A (InlA) and } \\
\text { Internalin B (InlB)] }\end{array}$ & $\begin{array}{l}1.5 \times 10^{4} \text { and } 1.2 \times 10^{5} \\
\mathrm{CFU} / \mathrm{mL} \text { in pure culture } \\
\text { for direct and competitive } \\
\text { formats, respectively }\end{array}$ & $4-8 \mathrm{~h}$ & 50 \\
\hline $\begin{array}{l}\text { Plastic-adherent DNA aptamer- } \\
\text { magnetic bead and QD sandwich assay }\end{array}$ & C. jejuni & $\begin{array}{l}2.5 \text { and } 10 \mathrm{CFU} / \mathrm{mL} \text { in } \\
\text { buffer and various food } \\
\text { matrices, respectively }\end{array}$ & $15-20 \mathrm{~min}$ & 51 \\
\hline $\begin{array}{l}\text { Fluorometric assay with indirect QD } \\
\text { labeling method based on antibody- }\end{array}$ & E. coli $\mathrm{O} 157: \mathrm{H} 7$ serotype & $\begin{array}{l}2.07 \times 10^{7} \mathrm{CFU} / \mathrm{mL} \text { in } \\
\text { PBS buffer }\end{array}$ & $5-6 \mathrm{~h}$ & 52 \\
\hline
\end{tabular}

antigen and streptavidin-biotin

interactions

\begin{tabular}{|c|c|c|c|c|}
\hline $\begin{array}{l}\text { Immunoassays for simultaneous } \\
\text { detection of two pathogenic bacterial } \\
\text { species using semiconductor QDs as } \\
\text { fluorescent labels }\end{array}$ & $\begin{array}{l}\text { E. coli } \mathrm{O} 157: \mathrm{H} 7 \text { and } S \text {. } \\
\text { typhimurium }\end{array}$ & $\begin{array}{l}10^{4} \mathrm{CFU} / \mathrm{mL} \text { in } \mathrm{PBS} \\
\text { buffer }\end{array}$ & Within $2 \mathrm{~h}$ & 53 \\
\hline $\begin{array}{l}\text { Optical detection using water-soluble } \\
\text { CdS QDs as a fluorescent marker of } \\
\text { immunoglobulins }\end{array}$ & Staphylococcus aureus & $\begin{array}{l}2.5 \times 10^{5} \mathrm{CFU} / \mathrm{mL} \text { in } \mathrm{PBS} \\
\text { buffer }\end{array}$ & About $1 \mathrm{~h}$ & 54 \\
\hline $\begin{array}{l}\text { Fluoroimmunoassays of multifood- } \\
\text { borne pathogenic bacteria based on } \\
\text { functionalized QDs coupled with } \\
\text { immunomagnetic separation }\end{array}$ & $\begin{array}{l}\text { S. typhimurium, Shigella } \\
\text { flexneri, and E. coli } \\
\text { O157:H7 }\end{array}$ & $\begin{array}{l}10^{3} \mathrm{CFU} / \mathrm{mL} \text { in food } \\
\text { matrix (apple juice and } \\
\text { milk) }\end{array}$ & Within $2 \mathrm{~h}$ & 55 \\
\hline $\begin{array}{l}\text { Quantitative characterization of QD- } \\
\text { labeled } E \text {. coli-specific lambda phage } \\
\text { by flow cytometry or } \\
\text { fluorescence microscopy }\end{array}$ & E. coli & $\begin{array}{l}10^{4} \mathrm{CFU} / \mathrm{mL} \text { in } \mathrm{PBS} \\
\text { buffer }\end{array}$ & About $1 \mathrm{~h}$ & 56 \\
\hline
\end{tabular}




\begin{tabular}{|c|c|c|c|c|}
\hline $\begin{array}{l}\text { Simultaneous detection of two } \\
\text { pathogenic bacterial species } \\
\text { by coupling immunomagnetic } \\
\text { separation } \\
\text { with QDs labeling }\end{array}$ & E. coli and S. enteritidis & $\begin{array}{l}5 \times 10^{2} \text { and } 4 \times 10^{2} \mathrm{CFU} / \\
\mathrm{mL} \text { for } E \text {. coli and } S . \\
\text { enteritidis, respectively, } \\
\text { in PBS }\end{array}$ & About $1 \mathrm{~h}$ & 57 \\
\hline $\begin{array}{l}\text { Immunoassay based on carbon } \\
\text { nanotube-enhanced ELISA }\end{array}$ & $\begin{array}{l}\text { S. enterica serovar } \\
\text { Typhimurium }\end{array}$ & $\begin{array}{l}10^{3} \text { and } 10^{4} \mathrm{CFU} / \mathrm{mL} \\
\text { for direct and sandwich } \\
\text { ELISA, respectively, in } \\
\text { PBS and food samples } \\
\text { (commercial UHT milk) }\end{array}$ & About $4 \mathrm{~h}$ & 62 \\
\hline $\begin{array}{l}\text { Ultrasensitive electrochemical } \\
\text { immunoassays of staphylococcal } \\
\text { enterotoxin B in food using enzyme- } \\
\text { nanosilica-doped carbon nanotubes for } \\
\text { signal amplification }\end{array}$ & $\begin{array}{l}\text { Staphylococcal } \\
\text { enterotoxin B (SEB) }\end{array}$ & $\begin{array}{l}10 \mathrm{pg} / \mathrm{mL} \text { in SEB-spiked } \\
\text { food samples (watermelon } \\
\text { juice, soymilk, apple } \\
\text { juice, and pork food) }\end{array}$ & About $2 \mathrm{~h}$ & 63 \\
\hline $\begin{array}{l}\text { Graphene-based nanoelectronic } \\
\text { biosensors using a semiconductor } \\
\text { device analyzer }\end{array}$ & $\begin{array}{l}\text { E. coli and glucose- } \\
\text { induced metabolic } \\
\text { activities }\end{array}$ & $10 \mathrm{CFU} / \mathrm{mL}$ in PBS buffer & About $2 \mathrm{~h}$ & 64 \\
\hline $\begin{array}{l}\text { Real-time potentiometric biosensors } \\
\text { using SWCNTs as transducers and } \\
\text { aptamers as biorecognition elements }\end{array}$ & $\begin{array}{l}\text { Pathogenic } E \text {. coli } \\
\text { O157:H7 toward } \\
\text { nonpathogenic } E \text {. coli } \\
\text { CECT } 657\end{array}$ & $\begin{array}{l}\text { 6-26 CFU/mL in in either } \\
\text { PBS or actual samples } \\
\text { (milk and apple juice) } \\
\text { (with extremely easy } \\
\text { pretreatment step of } \\
\text { samples) }\end{array}$ & About $1 \mathrm{~h}$ & 65 \\
\hline $\begin{array}{l}\text { Carbon nanotubes-based chemiresistive } \\
\text { biosensors using transduction element } \\
\text { of antibody-functionalized SWCNTs } \\
\text { aligned in parallel bridging two gold } \\
\text { electrodes }\end{array}$ & $\begin{array}{l}\text { E. coli } \mathrm{O} 157: \mathrm{H} 7 \text { and } \\
\text { bacteriophage } \mathrm{T} 7\end{array}$ & $\begin{array}{l}10^{3} \mathrm{CFU} / \mathrm{mL}\left(10^{1} \mathrm{CFU} /\right. \\
\text { chip) for } E \text {. coli } \mathrm{O} 157: \mathrm{H} 7 \\
10^{3} \mathrm{PFU} / \mathrm{mL}\left(10^{1} \mathrm{PFU} /\right. \\
\text { chip) for bacteriophage }\end{array}$ & $\begin{array}{l}\text { About } 5 \\
\text { min (for } \\
\text { bacteriophage); } \\
\text { about } 60 \text { min } \\
\text { (for bacteria) }\end{array}$ & 66 \\
\hline $\begin{array}{l}\text { Homogenous colorimetric method } \\
\text { based on self-assembled DNAzyme- } \\
\text { labeled DNA probes with SWCNT } \\
\text { conjugates }\end{array}$ & $\begin{array}{l}\text { Staphylococcus aureus } \\
\text { and its genomic DNA }\end{array}$ & $\begin{array}{l}1 \times 10^{5} \mathrm{CFU} / \mathrm{mL} \text { bacteria; } \\
30 \mathrm{nM} \text { target DNA in } \\
\text { buffer }\end{array}$ & $\begin{array}{l}\text { About } 15-20 \\
\mathrm{~h}\end{array}$ & 69 \\
\hline $\begin{array}{l}\text { Multiplexed immunoassay platforms } \\
\text { using metallic striped nanowires }\end{array}$ & $\begin{array}{l}\text { Three nonpathogenic } \\
\text { simulants: } \\
\text { 1) Bacillus globigii } \\
\text { (Bg) spores to simulate } \\
\text { Bacillus anthracis and } \\
\text { other bacterial species, } \\
\text { 2) RNA MS2 } \\
\text { bacteriophage to } \\
\text { simulate Variola (virus } \\
\text { for smallpox) and other } \\
\text { pathogenic viruses, and } \\
\text { 3) ovalbumin (Ova) to } \\
\text { simulate protein toxins } \\
\text { (e.g., ricin or botulinum } \\
\text { toxin) }\end{array}$ & $\begin{array}{l}10^{5} \mathrm{CFU} / \mathrm{mL}, 10^{5} \mathrm{PFU} / \\
\mathrm{mL}, \text { and } 5 \mathrm{ng} / \mathrm{mL} \\
\text { for Bg spores, MS2 } \\
\text { bacteriophage, and Ova } \\
\text { protein, respectively }\end{array}$ & Within 3-4 h & 73 \\
\hline $\begin{array}{l}\text { DNA detection using gold nanoparticle } \\
\text { functionalized } \\
\text { polyaniline nanofibers }\end{array}$ & $\begin{array}{l}\text { Staphylococcus aureus } \\
\text { causing maltitis }\end{array}$ & $\begin{array}{l}150 \times 10^{-12} \mathrm{~mol} / \mathrm{L} \text { target } \\
\text { DNA in buffer }\end{array}$ & About 8-10 h & 74 \\
\hline $\begin{array}{l}\text { Nanowire-labeled direct-charge transfer } \\
\text { biosensors }\end{array}$ & $\begin{array}{l}\text { Bacillus cereus and } B . \\
\text { anthracis }\end{array}$ & $10^{1}$ to $10^{2} \mathrm{CFU} / \mathrm{mL}$ & Within 6 min & 75 \\
\hline
\end{tabular}


3. Biosensor developments through magnetic nanoparticles-based pre-concentration

\begin{tabular}{|c|c|c|c|c|}
\hline $\begin{array}{l}\text { Assay of using biofunctional magnetic } \\
\text { nanoparticles in combination with } \\
\text { adenosine triphosphate (ATP) } \\
\text { bioluminescence }\end{array}$ & E. coli & $\begin{array}{l}20 \mathrm{CFU} / \mathrm{mL} \text { in bacterial- } \\
\text { cell inoculated pasteurized } \\
\text { milk }\end{array}$ & About $1 \mathrm{~h}$ & 77 \\
\hline $\begin{array}{l}\text { Antibody-coated paramagnetic beads } \\
\text { with fluorescence detection based on } \\
\text { conversion of 4-methylumbelliferyl- } \\
\text { beta-D-galactoside to } \\
\text { 4-methylumbelliferone by beta- } \\
\text { galactosidase }\end{array}$ & Viable E. coli & $8 \times 10^{4} \mathrm{CFU} / \mathrm{mL}$ in $\mathrm{PBS}$ & Less than $3 \mathrm{~h}$ & 78 \\
\hline $\begin{array}{l}\text { Magnetic-nanoparticle-based } \\
\text { magnetophoresis using biotin- } \\
\text { streptavidin system }\end{array}$ & E. coli $\mathrm{O} 157: \mathrm{H} 7$ & $\begin{array}{l}4.4 \times 10^{3} \mathrm{CFU} / \mathrm{mL} \text { in } \\
\text { buffer }\end{array}$ & About $3 \mathrm{~h}$ & 79 \\
\hline $\begin{array}{l}\text { SERS-based sandwich immunoassay } \\
\text { using antibody-coated magnetic } \\
\text { nanoparticles }\end{array}$ & E. coli & $8 \mathrm{CFU} / \mathrm{mL}$ in PBS & $\begin{array}{l}\text { Less than } 70 \\
\text { min }\end{array}$ & 80 \\
\hline $\begin{array}{l}\text { Preanalytical sample processing } \\
\text { methods using DNA-aptamer- } \\
\text { conjugated paramagnetic beads and } \\
\text { detection using quantitative real-time } \\
\text { RT-PCR }\end{array}$ & $\begin{array}{l}\text { S. enterica } \text { serovar } \\
\text { Typhimurium }\end{array}$ & $\begin{array}{l}10 \mathrm{CFU} / \mathrm{mL} \text { in pure } \\
\text { culture solution; } 10^{1} \text { and } \\
10^{2} \mathrm{CFU} / \mathrm{mL} \text { in bacterial- } \\
\text { cell-seeded whole carcass } \\
\text { chicken rinsate samples } \\
\text { using pull-down assay } \\
\text { and recirculation format, } \\
\text { respectively }\end{array}$ & About $3-5 \mathrm{~h}$ & 82 \\
\hline $\begin{array}{l}\text { Direct detection by magnetic- } \\
\text { nanoparticle-based DNA isolation } \\
\text { and PCR relying on paramagnetic- } \\
\text { nanoparticle-based isolation of bacterial } \\
\text { DNA and } \\
\text { listeriolysin O (hlyA) gene-specific } \\
\text { PCR }\end{array}$ & Listeria monocytogenes & $\begin{array}{l}10 \mathrm{CFU} / \mathrm{mL} \text { in pasteurized } \\
\text { whole milk }\end{array}$ & Within $7 \mathrm{~h}$ & 83 \\
\hline $\begin{array}{l}\text { Gold-nanorod-based selective } \\
\text { identification by two-photon Rayleigh } \\
\text { scattering spectroscopy }\end{array}$ & E. coli $\mathrm{O} 157: \mathrm{H} 7$ & $\begin{array}{l}50 \mathrm{CFU} / \mathrm{mL} \text { in aqueous } \\
\text { solution without } \\
\text { any amplification or } \\
\text { enrichment }\end{array}$ & $\begin{array}{l}\text { Less than } 15 \\
\text { min }\end{array}$ & 84 \\
\hline
\end{tabular}

The high polarizability and dielectrophoretic mobility of single-walled carbon nanotubes (SWCNTs) are used to trap and detect low numbers of bacterial cells in milliliter-sized samples. Attachment of the SWCNTs with both enhanced and reversed bacterial dielectrophoresis (DEP) mobility, leading to rapid assembly of SWCNTbacterium aggregates $(<5 \mathrm{~min})$ in conducting bridges between two electrodes by positivealternating current DEP. ${ }^{(31)}$ This technique showed a detection threshold of $10^{4} \mathrm{CFU} /$ $\mathrm{mL}$ of $E$. coli, suggesting that the functionalized SWCNTs may be used as absorbers and transporters of pathogens in biosensors. 
A novel immunological bead-free cell detection technique using QDs as reporter markers for food-borne pathogen detection has recently been introduced. ${ }^{(32)}$ The chemical compound (1-ethyl-3-3-dimethylaminopropyl) carbodiimide hydrochloride (EDC) and protein A were utilized as crosslinkers for preparing QD-antibody conjugates. To avoid interference by QD fluorescence, the beads were removed after primary pathogen separation and before fluorescence measurement. The combined approach of EDC-protein A QD labeling and bead-free fluorescence measurement could detect $E$. coli O157:H7 and Salmonella sp. as low as 10 CFU/g of artificially contaminated ground beef.

Furthermore, the PCR-based gold nanoparticle colorimetric method using thiollabeled primers has been established to amplify hly and hut specific to Listeria monocytogenes and Salmonella enterica, respectively. ${ }^{(33)}$ A PCR-product-linked gold nanoparticle displays a principally higher salt tolerance than a primer-linked gold nanoparticle; the facilitated gold-nanoparticle-based bacterial targets can be colorimetrically observed by the naked eyes or executively analyzed by spectrum measurement. The detection limits of the genomic DNA of L. monocytogenes and $S$. enterica are 0.015 and $0.013 \mathrm{ng} / \mathrm{mL}$, respectively, in artificially contaminated food samples.

Indeed, the potential utilization of antibody-conjugated fluorescent-dye-Rubpy-doped silica nanoparticles for immunofluorescence microscopy detection of various foodborne pathogens (i.e., Campylobacter jejuni, E. coli O157:H7, and Vibrio cholerae O1) has been achieved. ${ }^{(34-36)}$ This methodology has strong promise in improved pathogen detection by signal enhancement. ${ }^{(34)}$ This study indicated that Rubpy-dye-doped silica nanoparticles functionalized with a carboxyl group and conjugated with a $V$. cholerae $\mathrm{O} 1$ antibody could be effectively applied in signal amplification to detect a single target bacterial cell.

\section{Strategies for Biosensor Development for Food-Borne Pathogen Detection}

\subsection{Nanoparticle-based signal enhancement}

Because a bacterial cell is larger than a nanoparticle, a significant number of nanoparticles attach to each a bacterial cell; consequently, signal enhancement occurs (Fig. 2). ${ }^{37)}$ The effect of signal amplification on the sensitivity of the assay will depend on the optical or electrical properties of each nanoparticle (summarized in Table 2).

\subsubsection{Metallic nanoparticles}

Metallic nanoparticles (i.e., gold and silver) have been used for signal amplification in several biosensing devices. Gold nanoparticles have been widely applied in various optical and electrical assays.(38) Colorimetric assays based on a blue aggregated form and red dispersed solutions of gold nanoparticles were developed for the rapid detection of $S$. typhimurium and multidrug-resistant $S$. typhimurium DT104, ${ }^{(39,40)}$ with sensitivities of $10^{4}$ and $10^{3} \mathrm{CFU} / \mathrm{mL}$, respectively. Using SERS, the detection limit of S. typhimurium DT104 was decreased to $10 \mathrm{CFU} / \mathrm{mL}$. ${ }^{(41)}$ The electrical properties of the gold nanoparticles were oriented for the development of the piezoelectric biosensorbased real-time detection of a food-borne pathogen, E. coli O157:H7. Initially, targetspecific single-stranded DNA-functionalized gold nanoparticles were bound to the target 


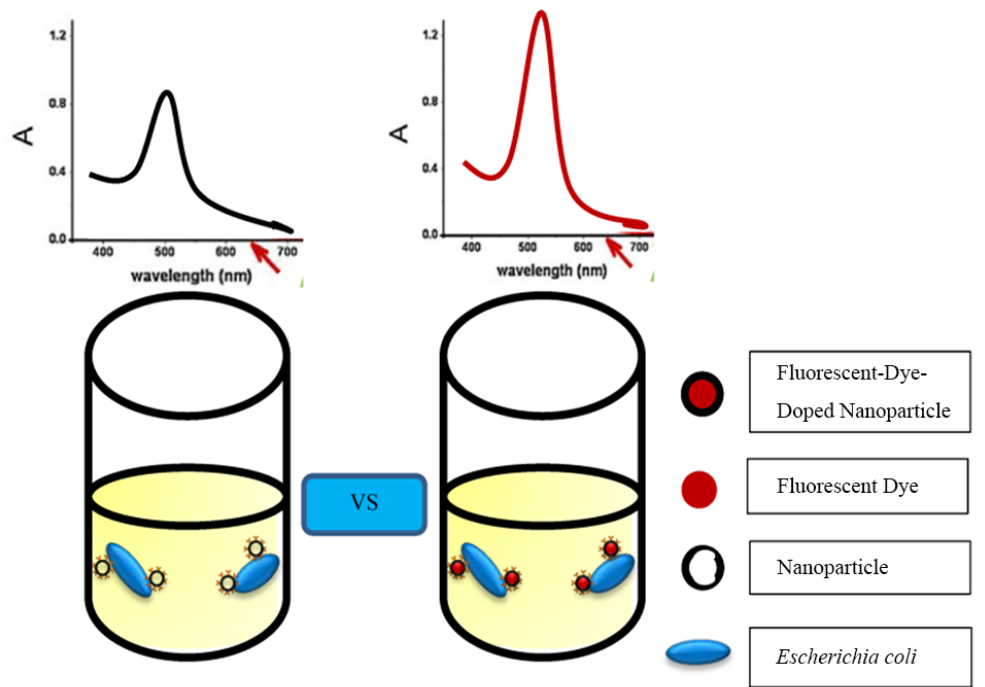

Fig. 2. (Color online) Scheme showing use of fluorescent-dye-doped nanoparticles for signal amplification in food-borne pathogen detection. Thousands of fluorescent dyes such as Rubpy with a high fluorescence signal intensity and a stable orange color can be doped inside each individual nanoparticle, resulting in enhanced signal intensity and eventually improved detection sensitivity. The intensity of the fluorescence signal is measured using an epifluorescence microscope or a confocal laser scanning electron microscope.

DNA and then to a complementary probe immobilized onto the piezoelectric biosensor surface, inducing a frequency shift of the piezoelectric biosensor. Concentrations as low as $1.2 \times 10^{2} \mathrm{CFU} / \mathrm{mL}$ E. coli $\mathrm{O} 157: \mathrm{H} 7$ were detectable. ${ }^{(42)}$

In addition, signal amplification of gold nanoparticles can be accomplished using silver. For example, a sandwich complex was developed using Salmonella sp.specific antibodies and antibody-coated gold nanoparticles. ${ }^{(43)}$ Subsequently, silver was coated around the gold nanoparticles, which facilitated the signal amplification in the chemiluminescence-based assay with a detection limit of $5 \mathrm{CFU} / \mathrm{mL}$. ${ }^{(44)}$ Similarly, an agressive approach using both gold and silver atoms on-slide was developed for the detection of the food-borne pathogen $C$. jejuni. This cost-effective detection format generated a high-intensity color that can easily be visualized by the unaided eye or determined using an inexpensive scanner.

A previous study using SERS with silver nanoparticles as a signal enhancer showed that six species of the Listeria genus including L. monocytogenes were distinguishable with the sensitivity of a single bacterial cell. ${ }^{(45,46)}$ Although this label-free assay possesses advantages in terms of simplicity and speed, it is often difficult to ascertain detection of multiple species with high specificity owing to similarity of SERS spectra. ${ }^{(47)}$ The use of SERS for detection of multiple pathogens with silica-coated magnetic probes functionalized with pathogen-specific antibodies was then developed for capture followed by detection using pathogen-specific SERS probes (gold nanoparticles integrated with a Raman reporter). ${ }^{(48)}$ The low sensitivity of detection $\left(10^{3} \mathrm{CFU} / \mathrm{mL}\right)$ of 
S. typhimurium and Staphylococcus aureus in complex food matrices (spinach solution and peanut butter) indicates the potential of the food-based assay format. Nevertheless, batch-to-batch variations in nanoparticle size that can affect the capability of SERS for a quantitative and reproducible assay may be a critical determinant.

\subsubsection{QDs}

QDs are colloidal semiconducting fluorescent nanoparticles that comprise a semiconductor material core (generally, cadmium mixed selenium or tellurium) coated with a semiconductor shell (normally, zinc sulphide). Owing to their unique size-related fluorescence quantums and photostability, QDs are extensively employed to replace traditional fluorescent dyes (e.g., fluorescein isothiocyanate, FITC). Functionalized QDs have been used as DNA labels for probing genomic DNA in fluorescence in situ hybridization (FISH) assays. ${ }^{(48)}$ Additionally, QDs have been used as fluorescent labels in various assays (particularly immunoassays) for the detection of food-borne pathogens such as L. monocytogenes, ${ }^{(49)}$ C. jejuni, ${ }^{(50)}$ E. coli $\mathrm{O} 157: \mathrm{H} 7,{ }^{(51)} S$. typhimurium, ${ }^{(52)} S$. aureus, ${ }^{(53)}$ and Shigella flexneri. ${ }^{(54)}$ A QD-based immunoassay for the sensitive detection of $S$. typhimurium in chicken carcass wash water (LOD, $10^{3} \mathrm{CFU} / \mathrm{mL}$ ) revealed the applicability of QDs in food matrices. ${ }^{(5)}$ As compared with traditional dyes, photostable, bright fluorescence intensities of QDs promoted signal amplification, resulting in lower detection thresholds. For instance, LOD of an immunoassay for E. coli O157:H7 detection demonstrated a 16 -fold decrease (from $3.33 \times 10^{8}$ to $2.08 \times 10^{7} \mathrm{CFU} / \mathrm{mL}$ ) when QDs served as the fluorescent label instead of FITC. ${ }^{(53)}$

For the development of functionalization strategies, QDs as labels were coupled to a variety of biorecognition elements, leading to versatility. In addition to antibody immobilized QDs, the detection of $S$. aureus using protein A-functionalized QDs was possible over the range of $2.5 \times 10^{5}$ to $1.0 \times 10^{8} \mathrm{CFU} / \mathrm{mL} .{ }^{(52)}$ Moreover, geneticallymodified bacteriophages coupled to QDs have been utilized for the detection of E. coli. ${ }^{(54)}$ Aptamer-linked QDs were employed in a sandwich assay in conjugation with magnetic beads for the detection of $C$. jejuni with reasonable sensitivity. ${ }^{(56)}$ This assay exhibited detection limits as low as 2.5 CFU in buffer and 10-250 CFU in different food matrices. The assay in conjugation with a sensitive handheld fluorometer that could offer rapid (within 15-20 $\mathrm{min}$ ) portable detection of food-borne contaminants might be recognized as a potential diagnostic tool.

The immediate detection of numerous biomarkers due to a broad Strokes shift is considered as one of the major advantages of QD utility, allowing the simultaneous excitation of several different QDs at a single excitation wavelength. The simultaneous detection of $E$. coli and $S$. enteritidis was improved by coupling immunomagnetic separation with QD labeling. ${ }^{(51)}$ Target-specific antibodies coupled to QDs with different emission wavelengths were used to label the captured bacteria, and the detection ranges were found to be $5 \times 10^{2}$ to $5 \times 10^{5} \mathrm{CFU} / \mathrm{mL}$ for $E$. coli and $4 \times 10^{2}$ to $4 \times 10^{5}$ $\mathrm{CFU} / \mathrm{mL}$ for $S$. enteritidis. Similarly, three species of food-borne pathogenic bacteria (S. typhimurium, Shigella flexneri, and E. coli O157:H7) were detectable using these multiplex assays in a single test, and the detection limits indicate high possibilities for cost-effective, rapid multiplex devices. ${ }^{(57)}$ 
Concerning the extensive application of QDs, challenges still remain. The sensitivity of QDs as labels was decreased when high concentrations of proteins were found in the food matrix. ${ }^{(55)}$ Quenching of the fluorescence signal also occurred when QDs were employed in combination with magnetic beads for bacterial capture. ${ }^{(55)}$ The complete replacement of traditional dyes by QDs is possibly due to their cost and size. Although QDs are in the nanoscale, they are still larger than the common dyes, probably resulting in biorecognition disturbance in multiplex assays.

\subsubsection{Nanotubes, nanofibers, and nanowires}

Carbon nanotubes (CNTs) are fabricated in different forms: SWCNTs are composed of single-atom-thick planar sheets of carbon atoms organized in a honeycomb lattice (graphene) and rolled into a cylinder-like tube; multi-walled carbon nanotubes (MWCNTs) consist of multiple tubes. In recent years, the functionalization of CNTs with proteins, nucleic acids, and antibodies has been extensively carried out. ${ }^{(57)}$ Concerning excellent electrical, physical, and optical properties, the CNT as a transducer has potential for signal amplification. ${ }^{(58-60)}$ By using a SWCNT/horseradish peroxidase (HRP)/antibody bioconjugate in an ELISA-based bioassay against $S$. typhimurium, a 1000-fold increase in detection sensitivity (LOD, $10^{4} \mathrm{CFU} / \mathrm{mL}$ ) was observed as compared with an HRPlabeled antibody (LOD, $10^{7} \mathrm{CFU} / \mathrm{mL}$ ). ${ }^{61)}$ Ultrasensitive detection (LOD, $10 \mathrm{pg} / \mathrm{mL}$ ) of staphylococcal enterotoxin B was achieved using an HRP-doped MWCNT-based signal amplification system in complex food matrices (i.e., watermelon juice, soymilk, apple juice, and pork). ${ }^{(62)}$

Rapid and real-time detection of food-borne pathogens is conceptual, and thus CNTbased electrodes are increasingly becoming nanosensing devices. The sensitive and label-free electrical detection of $E$. coli as low as $10 \mathrm{CFU} / \mathrm{mL}$ was accomplished using a graphene-based biosensor. ${ }^{(63)}$ A potentiometric aptamer-based biosensor showed striking changes in electrical potential after the interaction between the aptamer-functionalized SWCNT and the bacterial cell. Within a few minutes, pathogenic bacteria were detectable at as low as 6 and $26 \mathrm{CFU} / \mathrm{mL}$ in milk and apple juice, respectively. ${ }^{(64)}$ In addition, the multiplex CNT-based detection against both pathogens and viruses in food demonstrates advancements in food pathogen nanosensors. ${ }^{(65)}$ A CNT-based assay using antibody-functionalized SWCNT aligned with two gold electrodes displayed a detection limit for E. coli $\mathrm{O} 157: \mathrm{H} 7\left(10^{5} \mathrm{CFU} / \mathrm{mL}\right.$ within $\left.60 \mathrm{~min}\right)$ and for bacteriophage T7 $\left(10^{3}\right.$ plaque-forming units or $\mathrm{PFU} / \mathrm{mL}$ within $5 \mathrm{~min}$ ).

Interestingly, the CNTs enable protection of molecular probes. The interaction between nucleotide bases of single-stranded DNA (ssDNA) and side walls of SWCNT results in a stable complex that can protect ssDNA from degradation. ${ }^{(66)}$ By hybridization assay using a DNA-labeled probe, the protection of the SWCNT/ssDNA complex could definitely improve the detection sensitivity of $S$. aureus DNA (LOD, 30 $\mathrm{nM}$ ) compared with the hybridization without SWCNTs (LOD, $160 \mathrm{nM}$ ). ${ }^{(67-69)}$ This study has potential implications for molecular techniques in food matrices where the DNA probes can be easily degraded by cellular nucleases.

Recently, CNT-based sensing devices for food-borne pathogens have led to advancements in the sensitive, rapid, and label-free detection of the pathogens in food 
matrices. However, human health safety issues of CNTs, similar to other nanoparticles, and the fabrication processes become limiting factors. ${ }^{(69,70)}$ Reduction of CNT toxicity and the improvement of fabrication are somehow required if these devices remain appealing, rendering nano-biotechnologies promising for food-borne pathogen detection.

To complement CNTs, nanowires or nanofibers are considered promising nanomaterials for the electrical detection of analytes; however, electrical conductivity is poor owing to edge effects (atoms on the surface that are not fully bonded to their neighboring atoms) that can restrict the utility of nanowires. Ten E. coli $\mathrm{O} 157: \mathrm{H} 7$ cells were detectable using anti-E. coli-bound gold nanowire arrays in urine samples. Once a bacteria-antibody complex formed, an alteration in electrical potential was determined by electrochemical impedance spectroscopy. ${ }^{(71)}$ For multiplex immunoassays, a novel biosensing platform using engineered nanowires was established through a submicrometer layer of electrodeposited metals within a porous alumina template. ${ }^{(72)}$ After coating the nanowires with target-specific antibodies, sensitive multiplex detection of $B$. globiggi spores $\left(1 \times 10^{5} \mathrm{CFU} / \mathrm{mL}\right)$, MS2 bacteriophage $\left(1 \times 10^{5} \mathrm{PFU} / \mathrm{mL}\right)$, and ova protein $(5 \mathrm{ng} / \mathrm{mL})$ was achieved. S. aureus DNA at picomolar concentrations was detectable using gold nanoparticle-modified polyaniline nanofibers. ${ }^{(73)}$ The most potential nanowire-based assay for food-borne pathogen detection is a direct-charge transfer (DCT) biosensor toward B. cereus. This biosensor, fabricated using antibodies as sensing element and polyaniline nanowire as molecular electrical transducer, showed sensitivity in pure cultures of $10^{1}$ to $10^{2} \mathrm{CFU} / \mathrm{mL}$ within $6 \mathrm{~min} .{ }^{(74)}$ The rapid, sensitive, and portable biosensor makes it a promising device for in-line or on-site analysis in food supply chains. However, recent findings on the electrical detection of food-borne pathogens have attention on carbon nanotubes rather than nanowires or nanofibers. ${ }^{(75)}$

\subsection{Magnetic nanoparticle-based preconcentration}

Removal of a pre-enrichment step via magnetic separation technology combined with detection methods in food (i.e., color and opacity) is crucial and can expedite technology in the area of food safety. Magnetic nanoparticles coupled to a biorecognition element (i.e., antibodies, aptamers, or nucleic acids) are used for separating the target analyte from the matrix after a magnetic field is applied (Fig. 3 and Table 2). Owing to the high surface area-to-volume ratios of magnetic nanoparticles with high capture efficiencies, the immunocapture efficiency of $E$. coli using magnetic nanoparticles was higher than those of paramagnetic beads. ${ }^{76,77)}$ The paramagnetic beads, however, remain to be more extensively used than the magnetic nanoparticles. A magnetic-nanoparticlebased immunocapture for pathogenic bacteria detection is the most common approach applied to E. coli O157:H7, with capture efficiencies of $85-97 \%$ in buffer and $94 \%$ in beef sample. ${ }^{(78-80)}$ A decrease in immunocapture efficiency occurred when more than $10^{5}$ cells were present, ${ }^{(29)}$ reflecting a drawback of quantitative measurement of the pathogen. However, this level far exceeds permissible levels in food. ${ }^{(29)}$ The immunocapture-based nanomagnetic separation becomes the methodology of choice. Multiplex magnetic capture using amine-functionalized magnetic nanoparticles represented the simultaneous detection of B. cereus, E. coli, S. aureus, and Salmonella sp. with capture efficiencies of 97.4, 97.0, 66.5, and 55.0\%, respectively, whereas the application of aptamer-based magnetic particles was firstly achieved for capturing $S$. enterica from fecal samples and food matrix. ${ }^{(80,81)}$ 


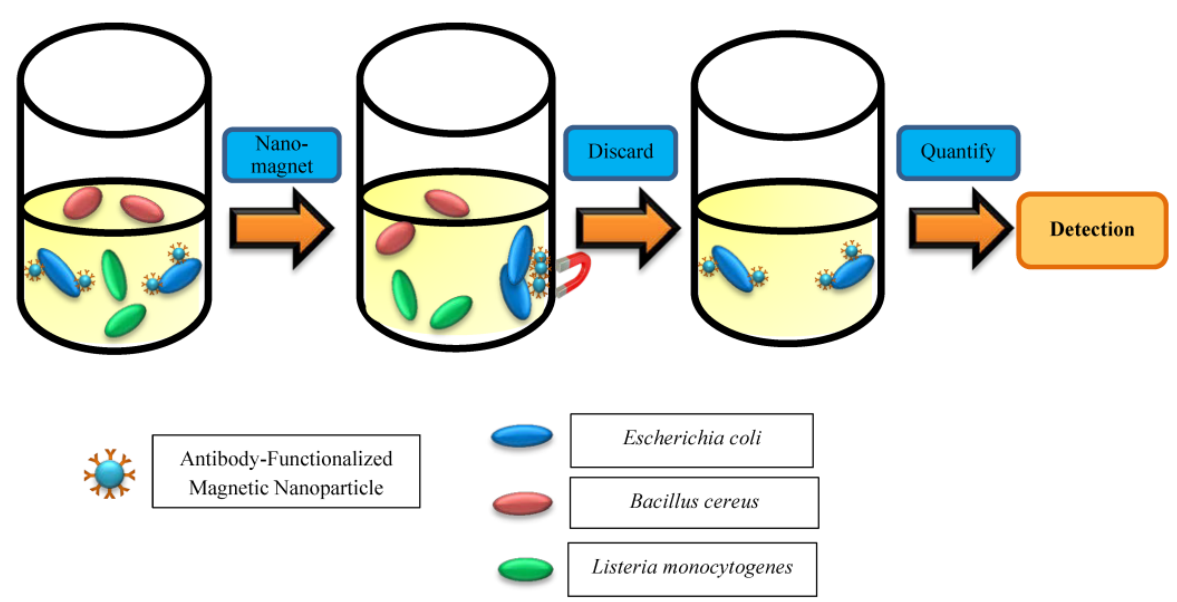

Fig. 3. (Color online) Scheme illustrating magnetic-nanoparticle-based detection method for capturing and concentrating target cells. For instance, selective antibodies specific to bacterial species (e.g., E. coli) are bound to the surface of magnetic nanoparticles. Only targeted microorganisms will be bound to the functionalized magnetic nanoparticles. Although a complex matrix (e.g., food, blood, milk, or cereal grains) contains a target analyte as well as several potential interferences such as other bacterial cells, the functionalized magnetic nanoparticles can selectively bind to the target analyte with high capture efficiency. Once a magnetic field is applied, analyte-bound magnetic particles are separated and the supernatant is then carefully discarded. The remaining materials are subjected to quantification assays.

Preconcentration of pathogenic bacteria via nanomagnetic separation coupled with sensitive detection approaches (i.e., chemiluminescence, "real-time" PCR, and QDs) resulted in lower detection limits and faster assays. Targeted paramagnetic nanoparticle-based separation of L. monocytogenes DNA extracted directly from milk and subsequently subjected to PCR amplification revealed excellent sensitivity as low as $10 \mathrm{CFU} / \mathrm{mL}$. ${ }^{(82)}$ A chemiluminescent nanomagnetic enzyme-linked immunoassay for the detection of E. coli O157:H7 showed a detection limit of 1000 cells $/ \mathrm{mL} .{ }^{(83)}$ Although magnetic nanoparticles offer the advantage of rapidity, the robust surface chemical immobilization of biorecognition molecules remains a challenge in the case of the more extensive use of magnetic nanoparticles.

\subsection{Improved antimicrobial efficacy of nanoparticles}

The utilization of nanoparticles (i.e., silver, titanium, zinc, and sulfur) as antimicrobial agents has increasingly gained attention. ${ }^{(84,85)}$ The antimicrobial activity of silver nanoparticles against food-borne pathogens (i.e., Bacillus cereus, E. coli, L. monocytogenes, S. aureus, and Salmonella sp.) was observed. ${ }^{(85-87)}$ Their antiviral and bactericidal activities against methicillin-resistant $S$. aureus (MRSA) and methicillinresistant S. epidermidis (MRSE) were also found. This antimicrobial feature of silver nanoparticles is considered to be due to the antimicrobial property of silver itself rather 
than the nanosize; other nanoparticles such as gold do not exhibit an inhibitory effect on growth. ${ }^{\left({ }^{87-91)}\right.}$ The toxicity of silver particles at the nanoscale was found to be increased relative to that of silver; this is due to the mechanism by which the nanoparticles, in terms of size and shape, can easily enter into a cell and release silver ions. ${ }^{(92)}$ Regarding environmentally friendly conscientiousness, this has led to the utility of microorganisms for the production of nanoparticles. ${ }^{(93)}$ These biogenic silver nanoparticles produced from Lactobacillus fermentum and Aspergillus clavatus displayed both antiviral and antibacterial activity comparable to those of chemically produced silver nanoparticles against an Enterobacter aerogenes-specific bacteriophage, murine norovirus 1 and Grampositive and Gram-negative bacteria. ${ }^{(94,95)}$ Silver nanoparticles as antimicrobial agents in various food packages could prolong the shelf life of the product. ${ }^{(89,96)}$

Numerous potential uses of nanoparticles have been reported in food or food packaging. ${ }^{(97-102)}$ Besides silver nanoparticles, titanium dioxide nanoparticles also have prominent antimicrobial properties owing to UV-mediated photocatalysis. ${ }^{(103-107)}$ Hence, UV irradiation is required for activating their antimicrobial activity. In the presence of $\mathrm{UV}$, titanium dioxide nanoparticles were effective against food-borne pathogens, particularly $L$. monocytogenes, Salmonella choleraesuis, and Vibrio parahaemolyticus. ${ }^{(103)}$ In foodpackages, ethylene vinyl alcohol $(\mathrm{EVOH})$ films thoroughly dispersed with titanium dioxide nanoparticles exhibited photo-activated antimicrobial activities against nine microorganisms, and consequently prevent food poisoning and spoilage. ${ }^{(108)}$ In addition, polypropylene films coated with titanium dioxide nanoparticles conferred antimicrobial properties against $E$. coli on fresh cut lettuce. ${ }^{(109)}$ A number of research studies have reported that combining titanium dioxide nanoparticles with silver nanoparticles could enhance antimicrobial efficacy against pathogens. ${ }^{(110,111)}$

Other nanoparticles harboring antimicrobial activity include those with magnesium oxide, ${ }^{(112-115)}$ copper and copper oxide, ${ }^{(97,116-124)}$ zinc oxide, ${ }^{(98-102,125-131)}$ cadmium selenide/ telluride, ${ }^{(132-134)}$ and chitosan, ${ }^{(135-137)}$ as well as carbon nanotubes. ${ }^{(138,139)}$ Zinc oxide nanoparticles exhibited potent antimicrobial activity against E. coli O157:H7, L. monocytogenes, and $S$. enteritidis. ${ }^{(140,141)}$ These findings suggest that zinc nanoparticles may distort and damage the bacterial cell membrane, leading to leakage of intracellular components and ultimately cell death. ${ }^{(142)}$ However, zinc nanoparticles suspended in polystyrene film displayed no antimicrobial activities, indicating limitation of its use in packaging. Surface-modified sulfur nanoparticles exhibited fungicidal efficacy against Aspergillus niger and Fusarium oxysporum. ${ }^{(143)}$ The antimicrobial potential of SCNTs against B. subtilis and E. coli was also observed. Nanotube networks produced on the surface of a bacterial cell were found to damage the bacterial envelopes, leading to intracellular leakage and cell death. ${ }^{(144)}$

Several studies have demonstrated the use of various classes of nanoparticles as antimicrobial agents in drinking water sterilization. ${ }^{(145)}$ Instead of sodium ions, silver ions dispersed in either poly(e-caprolactone) or poly(lactic acid) and applied in montmorillonite nanoclays, namely, "silver nanoclays", displayed potential antimicrobial activity. ${ }^{(146,147)}$

The efficacy of other antimicrobial agents in the presence of nanoparticles has been improved; this offers great promise for the reduction in the amount of pathogens in food. A highly complex structure of antimicrobial nanomaterials has also been developed. For instance, gold nanoparticles covalently attached with vancomycin 
exhibited higher bactericidal activity than vancomycin itself against even vancomycinresistant bacteria. ${ }^{(148)}$ Moreover, carbohydrate (phytoglycogen) nanoparticles loaded with nisin (This Lactococcus lactis-produced broad-spectrum antimicrobial peptide is widely used in the manufacture of processed cheeses, meats, and beverages) showed substantial antimicrobial potency against L. monocytogenes culture in comparison with uncoated nisin. ${ }^{(149)}$ A carbohydrate (phytoglycogen octenyl succinate) nanoparticlestabilized emulsion was found to extend the efficacy of the bacteriocin nisin against L. monocytogenes. ${ }^{(150)}$ Similarly, lysozyme-carrying nanoparticles functionalized with anti-L. monocytogenes showed higher effectiveness for inhibiting $L$. monocytogenes than the free lysozyme. ${ }^{(151)}$ In combination with the high binding affinity of CNTs to bacteria, the antibacterial effectiveness of inherent near-infrared (NIR) laser has been markedly improved whereas the cellular viability was affected neither by CNTs alone nor by NIR irradiations alone.(152) Generally, bacterial cell viability was reduced when bacteria conjugated to gold nanoparticles were exposed to NIR owing to photo-thermal lysis. ${ }^{(153)}$ These early applications of laser-activated nanoparticles as antimicrobial agents represented potential to eliminate disease-causing pathogens.

The utilization of nanoparticles as antimicrobial agents provides great promise. However, the biosafety of nanoparticles is still a health concern. ${ }^{(40)}$ The delineated processes by which nanoparticles kill bacteria and their health effects should be further warranted for their safe and extensive use in food or food processing.

\section{Advantages of Nanoparticle Application for Pathogen Detection}

\subsection{Fast and real-time detection}

Conventional culture-based methods involve steps of cell proliferation that take $24 \mathrm{~h}$ of incubation under laboratory conditions. Although DNA- and protein-based detection methods are quicker, these methods still take a relatively long period to carry out. In the case of a few bacterial cells in a food sample, a step of culture enrichment that may take from $2-3 \mathrm{~h}$ to overnight is principally required. The long period for obtaining results reflects cost-ineffectiveness and inconvenience particularly in the food industry.

By using an alternative nanoparticle-based method, the target cells are captured, discarded, or concentrated from sample specimens using biofunctionalized nanoparticles. The formation of a bio-nanoparticle-bacteria complex could then be determined within 2-3 min to hours without bacterial culture and enrichment.(26,154-159) In some cases, the use of impractical and expensive instruments (i.e., scanning electron microscopy (SEM), ${ }^{(160)}$ fluorescence microscopy, ${ }^{(161)}$ confocal scanning laser microscopy) was necessary to reduce the detection time in laboratory procedures. ${ }^{(162)}$

Furthermore, practical biosensors using nanoparticles have been developed to avoid the need for complicated instruments, allowing for the rapid and convenient detection of food-borne pathogens on a portable device. For instance, a single E. coli O157:H7 cell was detectable using a nanoparticle-based sensor in ground beef sample within $20 \mathrm{~min}$ as compared with up to $48 \mathrm{~h}$ in traditional tests. ${ }^{(156)}$ In principle, the fluorescent silica nanoparticles conjugated with anti-E.coli $\mathrm{O} 157$ were dispersed to ground beef inoculated with E. coli O157:H7. Antibody-conjugated nanoparticles bound to target cells were then determined using a flow cytometer. 
The small size of nanoparticles enables them to bind to target bacterial cells, significantly affecting their optical, physical, and chemical properties. This event allows the real-time detection of pathogenic bacteria depending on the mode of signal transduction or amplification. Indeed, several functionalized nanoparticle-based biosensors as pathogenic absorbers and transporters have been established. These nanoparticle-based biosensors require a detection period of within $10 \mathrm{~min}$. For example, the nanoparticle-based impedimetric biosensor consisting of the anti-Salmonella nanoparticles immobilized on interdigitated gold electrodes was employed to detect $\mathrm{S}$. enteritidis by measuring the impedance alterations after the target cells were bound. ${ }^{(26)}$ By using the nanoparticle-based biosensor, $10^{4} \mathrm{CFU} / \mathrm{mL}$ of $S$. enteritidis was detectable in phosphate-buffered saline (PBS) within 3 min.

\subsection{Enhanced detection sensitivity}

Food-borne pathogens at even low levels are still harmful to the health owing to their infectious ability and severity. For instance, in the United States, the presence of $L$. monocytogenes in ready-to-eat (RTE) food must be regulated under a "zero-tolerance" policy. ${ }^{(163)}$ Of concern, the "zero-tolerance" policy is implemented owing to the lack of rapid and reliable procedures for the low levels of detection of Listeria in foods. The utility of nanoparticles will thus be useful for the rapid and accurate detection of low levels of food-borne pathogens, as discussed and exemplified in a later section.

Fluorescent-dye-doped nanoparticles were developed as sensitive markers for Pathogen Detection owing to their favorable properties (i.e., high fluorescence quantum yields, photostability, and tunable fluorescence bands). ${ }^{(34-36,156,164)}$ A single nanoparticle $(<100 \mathrm{~nm}$ in size) can contain several hundreds of fluorescent dye molecules, becoming much brighter than a single fluorescent dye molecule. ${ }^{(164)}$ A bioassay based on fluorescent nanoparticles conjugated with anti-E.coli $\mathrm{O} 157$ was developed for the detection of $E$. coli $\mathrm{O} 157: \mathrm{H} 7$ in ground beef.(156) Owing to the tiny size of the fluorescent nanoparticle compared with the E. coli O157:H7 cell, a single bacterial cell was bound with thousands of anti-E.coli O157-conjugated fluorescent nanoparticles, resulting in enhanced fluorescent signals from the bacterial surfaces as the single E. coli $\mathrm{O} 157: \mathrm{H} 7$ cell was detectable.

Other fluorescent nanoparticles have also been successfully established for the sensitive detection of food-borne pathogens. Protein G-tagged liposomal nanovesicles were applied in an immunomagnetic bead sandwich assay for detecting E. coli O157:H7 with a detection limit of $100 \mathrm{CFU} / \mathrm{mL} .^{(165)}$ Each liposomal nanovesicle (i.e., liposome) can be filled with several millions of fluorescent dye molecules. With great signal enhancement, liposomal nanovesicles have been used as a potential reporter in immunoassays. Luminescence colloidal semiconductor nanocrystals, namely, QDs, were employed for detecting Cryptosporidium parvum oocyst. ${ }^{(166)}$ As compared with the organic fluorescent dye, QDs offer the beneficial feature of a high photobleaching threshold. By combining biotin-tagged E.coli-specific bacteriophage with streptavidincoated QDs, $10 \mathrm{CFU} / \mathrm{mL}$ of $E$. coli was detectable within an hour. ${ }^{(157)}$ By using multiple host-specific phages and QDs with different emission colors, this QD-phage-based method extensively provides the possibility of detecting multiple bacterial strains. 
The high surface area-to-volume ratio of nanoparticles potentiates them as substances for biomolecule immobilization. A DNA biosensor incorporating nanomembranes was successfully applied for detecting Pseudomonas aeruginosa. ${ }^{(15)}$ The surface area of nanomembranes is about 1- or 2-fold larger than that of continuous thin films, allowing increases consequently in the amount of bound DNA as well as response sensitivity. Application of the nanobead as a microfluid platform and its advantage for multiple target pathogen detection have been reported. ${ }^{(167)}$ Slow response time and low sensitivity attributable to low capture efficiency and long diffusion time reflect the limitation of microfluidics. Nanoparticle utilization is one of the research perspectives to overcome these limitations as the large local density of biomolecule-conjugated nanoparticles offers a greater capacity for capturing target bacterial cells in sample specimens, and consequently improves sensitivity and diffusion time.

Owing to the high surface area-to-volume ratio and rapid reactivity, the functionalized magnetic nanoparticles display higher capture efficiencies in immunomagnetic separation compared with microbeads. A minimal capture efficiency of $94 \%$ for E. coli $\mathrm{O} 157: \mathrm{H} 7$ ranging from $1.6 \times 10^{1}$ to $7.2 \times 10^{7} \mathrm{CFU} / \mathrm{mL}$ was measured using magnetic nanoparticleanti-E. coli $\mathrm{O} 157$ conjugates. ${ }^{(29)}$ In the presence of the background flora S. typhimurium DT104 cells, relatively low amounts of E. coli O157:H7 (400 CFU/mL) were captured using carbon magnetic nanotubes conjugated with anti-E.coli $\mathrm{O} 157$ without noticeable species cross reactivity. ${ }^{(168)}$ Nanoparticle-based immunomagnetic separation (IMS) and real-time PCR were combined for a speedy and quantitative detection of $L$. monocytogenes. ${ }^{(169)}$ The capture efficiencies of anti-L. monocytogenes magnetic-based IMS were higher than those of Dynabeads ${ }^{\circledR}$-based IMS when L. monocytogenes cells were inoculated into milk samples. By combining with real-time PCR, L. monocytogenes DNA was quantitatively detectable in milk samples with L. monocytogenes $\geq 2 \times 10^{2}$ $\mathrm{CFU} / \mathrm{mL}$.

Food-borne pathogen detection in biofilms is also a challenge. A microbial biofilm is defined as adherent microorganisms within a polymeric substance in a two- or threedimensional structure. Several food-borne pathogens can form biofilms with other microorganisms in food and processing environments. Inside biofilms, microbial cells become more resistant to sanitization than planktonic cells and are thus more difficult to eliminate.(170,171) Consequently, food-borne pathogens (i.e., L. monocytogenes) formed as biofilms are of serious concern in the food industry. Immuno-nanoparticlebased immunoassays showed higher sensitivity than conventional immunoassays for detecting L. monocytogenes in one- or two-species-containing biofilms, including $P$. aeruginosa ATCC 27853.(163) Using the same confocal laser scanning microscopy, nanoparticles coated with anti- $L$. monocytogenes (0-4000 arbitrary units) exhibited a higher intensity of fluorescent signals than anti-L. monocytogenes alone $(0-250$ arbitrary units). Individual L. monocytogenes cells at various depths $(0-5 \mu \mathrm{m})$ of two-speciescontaining biofilms were effectively detectable using the immuno-nanoparticle-based signal enhancement system.

\subsection{Multiplex detection of food-borne pathogens}

The optical features of nanoparticles (i.e., emissive, absorptive, and light-scattering properties) are associated with their sizes, composition, and shapes. For instance, the smaller the size of the QDs, the higher both the absorption and emission energies of the 
QD shift. ${ }^{172)}$ These characteristics render nanoparticles available for multiplex detection. Semiconductor QDs as fluorescence labels were used in simultaneous immunoassays for detecting the food-borne pathogens $E$. coli $\mathrm{O} 157: \mathrm{H} 7\left(1.95 \times 10^{3} \mathrm{CFU} / \mathrm{mL}\right)$ and $S$. typhimurium $\left(3.35 \times 10^{4} \mathrm{CFU} / \mathrm{mL}\right){ }^{(173)}$ Varying the numbers and ratios of different QDs per target generates distinct fluorescent signals for each individual target.

Instead of immunomagnetic beads, microtiter plates in an array format were successfully established for the simultaneous detection of E. coli O157:H7, Salmonella sp., and L. monocytogenes using the G-liposomes conjugated with selective antibodies. ${ }^{(174)}$ Apart from these nanovesicles, inorganic silica nanobeads doped with thousands of fluorescent dye molecules (Rubpy) that were conjugated with anti-E. coli O157 antibodies enable the binding of large numbers of nanoparticles onto individual bacterial cells via specific antibody-antigen recognition. ${ }^{(156)}$ Consistent with flow-cytometry-based measurements, these methodologies permit highly sensitive and simultaneous detection of one bacterial cell per given sample within 20 min using a spectrofluorometer in the presence of nontarget pathogens (i.e., S. typhimurium and B. cereus spores). About 1-400 E. coli $\mathrm{O} 157: \mathrm{H} 7$ cells were successfully detected using immunosilica nanoparticles even in spiked ground beef samples. The silica nanobeads were also doped with three amine reactive energy-transfer tandem dyes (FAM-SE, R6G-SE, and ROX-SE) in three ratios (1:0.5:1, 0.5:1:4, and 0.5:0.5:3) to generate different FRET nanoparticles. ${ }^{(159)}$ By conjugation with different pathogen-specific antibodies, multiplex detection of pathogens was conducted under confocal microscopy emitting three fluorescence signals (i.e., blue, orange, and purple) excited at $488 \mathrm{~nm}$.

On the basis of electric responses of nanowires due to multiplex pathogen binding via antibody-antigen interactions, an ultrahigh-density nanowire circuit has recently been developed and the combined electric signals have been decoded for individual pathogenic identification. ${ }^{(175)}$ Using optical signaling (i.e., reflectance and fluorescence) of fluorescently labeled antibodies, multistriped nanowires have been developed for the effective multiplex detection of biowarfare simulants. ${ }^{(73)}$ Antibody-conjugated nanowires with distinct identifiable encoding patterns were employed in the multiplex detection of three nonpathogenic stimulants, namely $B$. anthracis, Variola, and protein toxins (i.e., ricin or botulinum toxin) with detection limits of $1 \times 10^{5} \mathrm{CFU} / \mathrm{mL}, 1 \times 10^{5} \mathrm{PFU} / \mathrm{mL}$, and $5 \mathrm{ng} / \mathrm{mL}$, respectively.

\section{Conclusions}

In this review, we summarize current applications of nanoparticles to food-borne pathogen detection. In numerous studies, novel nanoparticle-based methods are applied to complement or replace traditional methods for the improvement of detection speediness and sensitivity. The utility of nanobiosensors has attracted increasing attention for "real-time" on-site analysis in food industrial or agricultural sectors.

Fluorescent nanoparticles were used for signal amplification whereas metal and semiconductor nanoparticles were selected for the development of biosensors, on the basis of their electronic or optical response as transducing signals. Herewith, bioconjugated nanoparticles have advantages over traditional (non-nanoparticle- 
based) methods for specific pathogen detection in both culture media and real sample specimens, including food products and biofilms. Furthermore, magnetic nanoparticles were extensively employed for eliminating disturbance from complex food matrices and for concentrating target microorganisms to avoid a step of time-extensive enrichment via a culture process.

The unique electronic, optical, and catalytic features are focused on for the development of novel nanoparticle-based detection methods. Major attempts have been oriented to the nanoparticle-based biosensors for time-intensive, simultaneous, and highthroughput detections of multiple target species. Interestingly, current nano-biosensorbased methodologies might be implemented for new emerging food-borne pathogen detection. Usually, biosensors lack the combined characteristics of high sensitivity and high specificity that are required for food-borne pathogen detection at an ultralow level. Moreover, research focusing on biosensor capacity improvement is needed.

More than 250 pathogens and their toxins are considered to be transmitted by food. The most important pathogens include Campylobacter sp., L. monocytogenes, Salmonella sp., Shiga-toxin-producing E. coli, Norovirus, and Toxoplasma gondii. As nanotechnology in detecting food-borne pathogens is still in the early stage, most of those studies have only been conducted on bacterial culture broths with E. coli strains being the microorganism. Although nanoparticle-based detection methods have been recently developed for certain pathogens (i.e., L. monocytogenes, Staphylococcus spp., Salmonella sp., and P. aeruginosa), further research studies focused on other potential food-borne pathogens (i.e., Campylobacter sp., Clostridium botulinum, and Vibrio sp. products) should be undertaken. Furthermore, more and new emerging pathogens are continuously identified and should be in focus.

Many nanoparticle-based procedures for pathogen detection still require highly complex and expensive instruments in a laboratory setting, which may be impractical in industrial sectors. Importantly, the toxicity of nanoparticles remains to be elucidated.

All these detection assays were currently processed without sample enrichment. In terms of speed, nanoparticle-based detection methods have the advantage of real-time pathogen detection. These methodologies may be very plausible for pathogen screening in food samples prior to highly skillful laboratory analysis. Although nanoparticle-based detection assays still so far need to be officially approved and accepted by customers, the prospect of nanoparticles for rapid and sensitive pathogen detection is probably applicable.

\section{Acknowledgements}

This research project was supported by the National Research Council of Thailand. This work was also supported by a grant from Mahidol University, Thailand, and by a grant from the Faculty of Environment and Resource Studies, Mahidol University, Thailand.

\section{References}

1 E. Scallan, R. M. Hoekstra, F. J. Angulo, R. V. Tauxe, M. A. Widdowson, S. L. Roy, J. L. Jones and P. M. Griffin: Emerg. Infect. Dis. 17 (2011) 7. 
2 R. L. Scharff: J. Food Prot. 75 (2012) 123.

3 S. Kumar, N. Dilbaghi, M. Barnela, G. Bhanjana and R. Kumar: BioNanoSci. 2 (2012) 196.

4 World Health Organization: WHO Technical Report No. 7051984 (1984).

5 F. Kaferstein: Bull. World Health Organ. 80 (2002) 759.

6 K. P. Burris and C. N. Stewart: Trends Food Sci. Technol. 28 (2012) 143.

7 A. V. Hadjinicolaou, V. L. Demetriou, J. Hezka, W. Beyer, T. L. Hadfield and L. G. Kostriki: J. Microbiol. Meth. 78 (2009) 45.

8 S. H. Liming and A. A. Bhagwat: Int. J. Food Microbiol. 95 (2004) 177.

9 T. V. Duncan: J. Colloid Interface Sci. 363 (2011) 1.

10 J. Heo and S. Z. Hua: Sensors 9 (2009) 4483.

11 N. Sanvicens, C. Pastells, N. Pascual and M. P. Marco: Trends Anal. Chem. 28 (2009) 1243.

12 P. Tallury, A. Malhotra, L. M. Byrne and S. Santra: Adv. Drug Deliver. Rev. 62 (2010) 424.

13 M. Tietjen and D. Y. C. Fung: Crit. Rev. Microbiol. 21 (1995) 53.

14 T. Humphrey and P. Stephens: Salmonella detection, eds. B. Caballero, L. Trugo and P. Finglas (Academic Press, New York, 2003) pp. 5079-5084.

15 V. Velusamy, K. Arshak, O. Korostynska, K. Oliwa and C. Adley: Biotechnol. Adv. 28 (2010) 232.

16 H. G. Shen, S. Gould, J. Kinyon, T. Opriessnig and A. M. O’Connor: J. Appl. Microbiol. 111 (2011) 1037.

17 J. Chen, J. Tang, J. Liu, Z. Cai and X. Bai: J. Appl. Microbiol. 112 (2012) 823.

18 D. D. L. Bowtell: Nature General Supplement 21 (1999) 25.

19 G. H. W. Sanders and A. Manz: Trends Anal. Chem. 19 (2000) 364.

20 J. Wan, K. King, H. Craven, C. Mcauley, S. E. Tan and M. J. Coventry: Lett. Appl. Microbiol. 30 (2000) 267.

21 S. Nawaz: Pesticides and Herbicides. Residue determination, eds B. Caballero, L. Trugo and P. Finglas (Academic Press, New York, 2003) pp. 4487-4493.

22 V. Polan, J. Soukup and K. Vytras: SAGE-hindawi access to research enzyme research 2010 (2010) doi:10.4061/2010/324184.

23 J. Reyes and R. P. Cavalieri: Biosensors. Encyclopedia of Agricultural and Food Engineering, ed. D. R. Heldman (Marcel Dekker, New York, 2003) pp. 119-123.

24 L. A. Terry, S. F. White and L. J. Tigwell: J. Agric. Food Chem. 53 (2005) 1309.

25 M. S. Thakurm and K. V. Ragavan: J. Food Sci. Technol. 50 (2013) 625.

26 G. Kim, A. S. Om and J. H. Mun: J. Phys. Conf. Ser. 61 (2007) 555.

27 G. Y. Zhao, F. F. Xing and S. P. Deng: Electrochem. Commun. 9 (2007) 1263.

28 C. C. Lin, Y. C. Yeh, C. Y. Yang, C. L. Chen, G. F. Chen, C. C. Chen and Y. C. Wu: J. Am. Chem. Soc. 124 (2002) 3508.

29 M. Varshney, L. Yang, X. L. Su and Y. Li: J. Food Prot. 68 (2005) 1804.

30 M. Basu, S. Seggerson, J. Henshaw, J. Jiang, R. Cordona, C. Lefave, P. J. Boyle, A. Miller, M. Pugia and S. Basu: Glycoconjugate J. 21 (2004) 487.

31 R. Zhou, P. Wang and H. C. Chang: Electrophoresis 27 (2006) 1376.

32 L. Wang, C. S. Wu, X. Fan and A. Mustapha: Int. J. Food Microbiol. 156 (2012) 83.

33 Z. Fu, X. Zhou and D. Xing: Sens. Actuators, B 183 (2013) 633.

34 N. Thepwiwatjit, A. Thattiyaphong, P. Limsuwan, K. Tuitemwong and P. Tuitemwong: J. Nanomaterials 2013 (2013) 1.

35 W. Tansub, K. Tuitemwong, P. Limsuwan, S. Theparoonrat and P. Tuitemwong: J. Nanomaterials 2012 (2012) 1.

36 P. Tuitemwong, N. Songvorawit and K. Tuitemwong: J. Nanomaterials 2013 (2013) 1.

37 T. Soukka, K. Antonen, H. Harma, A. M. Pelkkikangas, P. Huhtinen and T. Lovgren: Clin. Chim. Acta 328 (2003) 45.

38 P. Baptista, E. Pereira, P. Eaton, G. Doria, A. Miranda, I. Gomes, P. Quaresma and R. Franco: Anal. Bioanal. Chem. 391 (2008) 943. 
39 M. Vidotti, R. F. Carvalhal, R. K. Mendes, D. C. M. Ferreira and L. T. Kubota: J. Brazilian Chem. Soc. 22 (2011) 3.

40 S. Wang, A. K. Singh, D. Senapati, A. Neely, H. Yu and P. C. Ray: Chem. Eur. J. 16 (2010) 5600 .

41 S. A. Khan, A. K. Singh, D. Senapati, Z. Fan and P. C. Ray: Chem. Commun. 47 (2011) 9444.

42 A. Jyoti, P. Pandey, S. P. Singh, S. K. Jain and R. Shanker: J. Nanosci. Nanotechnol. 10 (2010) 4154.

43 S. Chen, V. C. H. Wu, Y. Chuang and C. Lin: J. Microbiol. Methods 73 (2008) 7.

44 Z. Wang, N. Duan, J. Li, J. Ye, S. Ma and G. Le: J. Lumin. 26 (2011) 136.

45 C. Cao, L. C. Gontard, L. L. Tram, A. Wolff and D. D. Bang: Small 7 (2011) 1701.

46 G. C. Green, A. D. C. Chan, B. S. Luo, H. Dan and M. Lin: IEEE Trans. Instrum. Meas. 58 (2009) 3713.

47 M. Kahraman, M. M. Yazici, F. Sahin, O. F. Bayrak, E. Topcu and M. Culha: Int. J. Environ. Anal. Chem. 87 (2007) 763.

48 Y. Wang, S. Ravindranath and J. Irudayaraj: Anal. Bioanal. Chem. 399 (2011) 1271.

49 A. C. Vinayaka and M. S. Thakur: Anal. Bioanal. Chem. 397 (2010) 1445.

50 E. Tully, S. Hearty, P. Leonard and R. O'Kennedy: Int. J. Biol. Macromol. 39 (2006) 127.

51 J. G. Bruno, T. Phillips and M. P. Carrillo: J. Fluoresc. 19 (2009) 427.

52 M. Hahn, J. Tabb and T. Krauss: Anal. Chem. 77 (2005) 4861.

53 L. Yang and Y. Li: Analyst 131 (2006) 394.

54 Z. De Liu, S. F. Chen, C. Z. Huang, S. J. Zhen and Q. G. Liao: Anal. Chim. Acta 599 (2007) 279.

55 Y. Zhao, M. Ye, Q. Chao, N. Jia, Y. Ge and H. Shen: J. Agric. Food Chem. 57 (2009) 517.

56 P. B. Yim, M. L. Clarke, M. McKinstry, S. H. Lacerda, L. F. Pease, M. A. Dobrovolskaia, H. Kang, T. D. Read, S. Sozhamannan and J. Hwang: Biotechnol. Bioeng. 104 (2009) 1059.

57 F. C. Dudak and I. H. Boyaci: J. Rapid Methods Autom. Microbiol. 17 (2009) 315

58 C. Crean (nee Lynam), E. Lahiff, N. Gilmartin, D. Diamond and R. O'Kennedy: Synth. Met. 161 (2011) 285.

59 C. Lynam, N. Gilmartin, A. I. Minett, R. O’Kennedy and G. Wallace: Carbon 47 (2009) 2337.

60 J. W. Lee, K. M. Shin, C. Lynam, G. M. Spinks, G. G. Wallace and S. J. Kim: Smart Mater. Struct. 17 (2008) 045029.

61 E. Lahiff, C. Lynam, N. Gilmartin, R. O’Kennedy and D. Diamond: Anal. Bioanal. Chem. 398 (2010) 1575.

62 W. Chunglok, D. K. Wuragil, S. Oaew, M. Somasundrum and W. Surareungchai: Biosens. Bioelectron. 26 (2011) 3584.

63 D. Tang, J. Tang, B. Su and G. Chen: J. Agric. Food Chem. 58 (2010) 10824.

64 Y. Huang, X. Dong, Y. Liu, L. Li and P. Chen: J. Mater. Chem. 21 (2011) 12358.

65 G. A. Zelada-Guillen, S. V. Bhosale, J. Riu and F. Rius: Anal. Chem. 82 (2010) 9254.

66 C. Garcia-Aljaro, L. N. Cella, D. J. Shirale, M. Park, F. J. Munoz, M. V. Yates and A. Mulchandani: Biosens. Bioelectron. 26 (2010) 1437.

67 X. Tang, S. Bansaruntip, N. Nakayama, E. Yenilmez, Y. Chang and Q. Wang: Nano Lett. 6 (2006) 1632.

68 R. Yang, Z. Tang, J. Yan, H. Kang, Y. Kim, Z. Zhu and W. Tan: Anal. Chem. 80 (2008) 7408.

69 X. Ding, H. Li, L. Deng, Z. Peng, H. Chen and D. Wang: Biosens. Bioelectron. 26 (2011) 4596.

70 J. Kaiser, M. Roesslein, T. Buerki-Thurnherr and P. Wick: Curr. Med. Chem. 18 (2011) 2115.

71 G. D. Nessim: Nanoscale 2 (2010) 1306.

72 M. Basu, S. Seggerson, J. Henshaw, J. Jiang, R. D. Cordona, C. Lefave, P. J. Boyle, A. Miller, M. Pugia and S. Basu: Glycoconjugate J. 21 (2004) 487.

73 J. B. Tok, F. Y. S. Chuang, M. C. Kao, K. A. Rose, S. S. Pannu, M. Y. Sha, G. Chakarova, S. G. Penn and G. M. Dougherty: Angew. Chem. Int. Ed. 45 (2006) 6900. 
74 E. Spain, R. Kojima, R. B. Kaner, G. G. Wallace, J. O’Grady, K. Lacey, T. Barry, T. E. Keyes and R. J. Forster: Biosens. Bioelectron. 26 (2011) 2613.

75 S. Pal, E. C. Alocilja and F. P. Downes: Biosens. Bioelectron. 22 (2007) 2329.

76 F. Patolsky, G. Zheng and C. M. Lieber: Nat. Protoc. 1 (2006) 1711.

77 Y. Cheng, Y. Liu, J. Huang, K. Li, W. Zhang, Y. Xian and L. Jin: Talanta 77 (2009) 1332.

78 F. C. Dudak, I. H. Boyaci, A. Jurkevica, M. Hossain, Z. Aquilar, H. B. Halsall, C. J. Seliskar and W. R. Heineman: Anal. Bioanal. Chem. 393 (2009) 949.

79 H. Huang, C. Ruan, J. Lin, M. Li, L. M. Cooney, W. F. Oliver, Y. Li and A. Wang: Trans. ASABE 54 (2011) 1015.

80 B. Guven, N. Basaran-Akgul, E. Temur, U. Tamer and I. H. Boyaci: Analyst 136 (2011) 740.

81 Y. Huang, Y. Wang and X. Yan: Environ. Sci. Technol. 44 (2010) 7908.

82 R. Joshi, H. Janagama, H. P. Dwivedi, T. M. A. S. Kumar, L. Jaykus, J. Schefers and S. Sreevatsan: Mol. Cell. Probes 23 (2009) 20.

83 G. Amagliani, G. Brandi, E. Omiccioli, A. Casiere, I. Bruce and M. Magnani: Food Microbiol. 21 (2004) 597.

84 A. K. Singh, D. Senapati, S. Wang, J. Griffin, A. Neely, P. Candice, K. M. Naylor, B. Varisli, J. R. Kalluri and P. C. Ray: ACS Nano. 3 (2009) 1906.

85 T. V. Duncan: J. Colloid. Interface. Sci. 363 (2011) 1.

86 P. Dallas, V. K. Sharma and R. Zboril: Adv. Colloid Interface Sci. 166 (2011) 119.

87 H. H. Lara, E. N. Garza-Trevino, L. Ixtepan-Turrent and D. K. Singh: J. Nanobiotechnol. 9 (2011) 30.

88 Q. Feng, J. Wu, G. Chen, F. Cui, T. Kim and J. Kim: J. Biomed. Mater. Res. 52 (2000) 662.

89 B. De Gusseme, L. Sintubin, L. Baert, E. Thibo, T. Hennebel, G. Vermeulen, M. Uyttendaele, W. Verstraete and N. Boon: Appl. Environ. Microbiol. 76 (2010) 1082.

90 S. S. Khan, A. Mukherjee and N. Chandrasekaran: Colloid Surf. B 87 (2011) 129.

91 S. Egger, R. P. Lehmann, M. J. Height, M. J. Loessner and M. Schuppler: Appl. Environ. Microbiol. 75 (2009) 2973.

92 J. S. Kim, E. Kuk, K. N. Yu, J. Kim, S. J. Park, H. J. Lee, S. H. Kim, Y. K. Park, Y. H. Park, C. Y. Hwang, Y. S. Lee, D. H. Jeong and M. H. Cho: Nanomed.-Nanotechnol. Biol. Med. 3 (2007) 95.

93 L. K. Limbach, P. Wick, P. Manser, R. N. Grass, A. Bruinink and W. J. Stark: Environ. Sci. Technol. 41 (2007) 4158.

94 T. N. V. K. V. Prasad, V. S. R. Kambala and R. Naidu: Curr. Nanosci. 7 (2011) 531.

95 M. Saravanana and A. Nanda: Colloid Surf. B 77 (2010) 214.

96 L. Sintubin, B. Gusseme, P. Meeren, B. F. G. Pycke, W. Verstraete and N. Boon: Appl. Microbiol. Biotechnol. 91 (2011) 153.

97 G. Cárdenas, J. Díaz, M. F. Meléndrez, C. Cruzat and A. García: Polym. Bull. 62 (2009) 511.

98 T. Jin, D. Sun, J. Y. Su, H. Zhang and J. Sue: J. Food Sci. 74 (2009) M46.

99 X. Li, Y. Xing, Y. Jiang, Y. Ding and W. Li: Int. J. Food Sci. Technol. 44 (2009) 2161.

100 Y. Liu, L. He, A. Mustapha, H. Li, Z. Q. Hu and M. Lin: J. Appl. Microbiol. 107 (2009) 1193.

101 S. K. Bajpai, N. Chand and V. Chaurasia: J. Appl. Polym. Sci. 115 (2010) 674.

102 Y. Xie, Y. He, P. L. Irwin, T. Jin and X. Shi: Appl. Environ. Microbiol. 77 (2011) 2325.

103 B. Kim, D. Kim, D. Cho and S. Cho: Chemosphere 52 (2003) 277.

104 J. M. C. Robertson, P. K. J. Robertson and L. A. Lawton: J. Photochem. Photobiol. 175 (2005) 51.

105 G. Fu, P. S. Vary and C. Lin: J. Phys. Chem. B 109 (2005) 8889.

106 W. Kangwansupamonkon, V. Lauruengtana, S. Surassmo and U. Ruktanonchai: Nanomed.Nanotechnol. Biol. Med. 5 (2009) 240.

107 A. Kubacka, M. L. Cerrada, C. Serrano, M. Fernández-García, M. Ferrer and M. FernándezGarcía: J. Phys. Chem. C 113 (2009) 9182. 
108 M. L. Cerrada, C. Serrano, M. Sánchez-Chaves, M. Fernández-García, F. Fernández-Martín, A. Andrés, R. J. J. Riobóo, A. Kubacka, M. Ferrer and M. Fernández-García: Adv. Funct. Mater. 18 (2008) 1949.

109 C. Chawengkijwanich and Y. Hayata: Int. J. Food Microbiol. 123 (2008) 288.

110 Q. Cheng, C. Li, V. Pavlinek, P. Saha and H. Wang: Appl. Surf. Sci. 252 (2006) 4154.

111 T. S. Wu, K. X. Wang, G. D. Li, S. Y. Sun, J. Sun and J. S. Chen: ACS Appl. Mater. Int. 2 (2010) 544.

112 P. K. Stoimenov, R. L. Klinger, G. L. Marchin and K. J. Klabunde: Langmuir 18 (2002) 6679.

113 L. Huang, D. Q. Li, D. G. Evans and X. Duan: Eur. Phys. J. D 34 (2005) 321.

114 L. Huang, D. Q. Li, Y. J. Lin, M. Wei, D. G. Evans and X. Duan: J. Inorg. Biochem. 99 (2005) 986.

115 Y. J. Lin, D. Q. Li, G. Wang, L. Huang and X. Duan: J. Mater. Sci. Mater. Med. 16 (2005) 53.

116 K. Y. Yoon, J. Hoon Byeon, J. H. Park and J. Hwang: Sci. Total Environ. 373 (2007) 572.

117 N. Cioffi, L. Torsi, N. Ditaranto, G. Tantillo, L. Ghibelli, L. Sabbatini, T. Bleve-Zacheo, M. D'Alessio, P. G. Zambonin and E. Traversa: Chem. Mater. 17 (2005) 5255.

118 G. Mary, S. K. Bajpai and N. Chand: J. Appl. Polym. Sci. 113 (2009) 757.

119 K. C. Anyaogu, A. V. Fedorov and D. C. Neckers: Langmuir 24 (2008) 4340.

120 L. Esteban-Tejeda, F. Malpartida, A. Esteban-Cubillo, C. Pecharromán and J. S. Moya: Nanotechnology 20 (2009) 505701.

121 G. Ren, D. Hu, E. W. C. Cheng, M. A. Vargas-Reus, P. Reip and R. P. Allaker: Int. J. Antimicrob. Agents 33 (2009) 587.

122 I. Perelshtein, G. Applerot, N. Perkas, E. Wehrschuetz-Sigl, A. Hasmann, G. Guebitz and A. Gedanken: Surf. Coat. Technol. 204 (2009) 54.

123 H. Palza, S. Gutiérrez, K. Delgado, O. Salazar, V. Fuenzalida, J. I. Avila, G. Figueroa and R. Quijada: Macromol. Rapid Commun. 31 (2010) 563.

124 F. Rispoli, A. Angelov, D. Badia, A. Kumar, S. Seal and V. Shah: J. Hazard. Mater. 180 (2010) 212.

125 A. Emamifar, M. Kadivar, M. Shahedi and S. Soleimanian-Zad: Food Control 22 (2011) 408.

126 K. H. Tam, A. B. Djurišić, C. M. N. Chan, Y. Y. Xi, C. W. Tse, Y. H. Leung, W. K. Chan, F. C. C. Leung and D. W. T. Au: Thin Solid Films 516 (2008) 6167.

127 G. Droval, I. Aranberri, A. Bilbao, L. German, M. Verelst and J. Dexpert-Ghys: e-Polymers 8 (2013) 1467.

128 B. A. Sevinç and L. Hanley: J. Biomed. Mater. Res. B 94 (2010) 22.

129 S. Lee: J. Appl. Polym. Sci. 114 (2009) 3652.

130 V. Chaurasia, N. Chand and S. K. Bajpai: J. Macromol. Sci. Pure Appl. Chem. 47 (2010) 309.

131 D. Yuvaraj, R. Kaushik and K. N. Rao: ACS Appl. Mater. Int. 2 (2010) 1019.

132 Z. Lu, C. M. Li, H. Bao, Y. Qiao and Q. Bao: J. Nanosci. Nanotechnol. 9 (2009) 3252.

133 Z. Lu, C. M. Li, H. Bao, Y. Qiao, Y. Toh and X. Yang: Langmuir 24 (2008) 5445.

134 J. H. Priester, P. K. Stoimenov, R. E. Mielke, S. M. Webb, C. Ehrhardt, J. P. Zhang, G. D. Stucky and P. A. Holden: Environ. Sci. Technol. 43 (2009) 2589.

135 L. Qi, Z. Xu, X. Jiang, C. Hu and X. Zou: Carbohydr. Res. 339 (2004) 2693.

136 Y. H. Lu, Y. Y. Chen, H. Lin, C. Wang and Z. D. Yang: J. Appl. Polym. Sci. 117 (2010) 3362.

137 K. Xing, X. G. Chen, M. Kong, C. S. Liu, D. S. Cha and H. J. Park: Carbohydr. Polym. 76 (2009) 17.

138 S. Kang, M. Pinault, L. D. Pfefferle and M. Elimelech: Langmuir 23 (2007) 8670.

139 S. Kang, M. S. Mauter and M. Elimelech: Environ. Sci. Technol. 43 (2009) 2648.

140 C. Costa, A. Conte, G. G. Buonocore and M. A. Nobile: Int. J. Food Microbiol. 148 (2011) 164.

141 A. L. Incoronato, A. Conte, G. G. Buonocore and M. A. Nobile: J. Dairy Sci. 94 (2011) 1697.

142 T. Jin, D. Sun, J. Y. Su, H. Zhang and H. Sue: J. Food Sci. 74 (2009) M46. 
143 Y. Liu, L. He, A. Mustapha, H. Li, Z. Q. Hu and M. Lin: J. Appl. Microbiol. 107 (2009) 1193.

144 S. R. Choudhury, M. Ghosh, A. Mandal, D. Chakravorty, M. Pal, S. Pradhan and A. Goswami: Appl. Microbiol. Biotechnol. 90 (2011) 733.

145 Q. Li, S. Mahendra, D. Y. Lyon, L. Brunet, M. V. Liga, D. Li and P. J. J. Alvarez: Water Res. 42 (2008) 4591.

146 A. L. Incoronato, G. G. Buonocore, A. Conte, M. Lavorgna and M. A. Del Nobile: J. Food Prot. 73 (2010) 2256.

147 M. A. Busolo, P. Fernandez, M. J. Ocio and J. M. Lagaron: Food Addit. Contam. Part A 27 (2010) 1617.

148 H. Gu, P. L. Ho, E. Tong, L. Wang and B. Xu: Nano Lett. 3 (2003) 1261.

149 L. Bi, L. Yang, G. Narsimhan, A. K. Bhunia and Y. Yao: J. Controlled Release 150 (2011) 150 .

150 S. Liu, A. K. Ng, R. Xu, J. Wei, C. M. Tan, Y. Yang and Y. Chen: Nanoscale 2 (2010) 2744.

151 L. Bi, L. Yang, A. K. Bhunia and Y. Yao: Biotechnol. Bioeng. 108 (2011) 1529.

152 H. Yang, L. Qu, A. Wimbrow, X. Jiang and Y. Sun: J. Food Prot. 70 (2007) 1844.

153 J. Kim, E. V. Shashkov, E. I. Galanzha, N. Kotagiri and V. P. Zharov: Lasers Surg. Med. 39 (2007) 622.

154 L. Qu, P. G. Luo, S. Taylor, Y. Lin, W. Huang, N. Anyadike, T. R. Tzeng, F. Stutzenberger, R. A. Latour and Y. P. Sun: J. Nanosci. Nanotechnol. 5 (2005) 319.

155 F. He and S. Liu: Talanta 62 (2004) 271.

156 X. Zhao, L. R. Hilliard, S. J. Mechery, Y. Wang, R. P. Bagwe, S. Jin and W. Tan: PNAS 101 (2004) 15027.

157 R. Edgar, M. McKinstry, J. Hwang, A. B. Oppenheim, R. A. Fekete, G. Giulian, C. Merril, K. Nagashima and S. Adhya: Proc. Natl. Acad. Sci. U.S.A 103 (2006) 4841.

158 K. El-Boubbou, C. Gruden and X. Huang: J. Am. Chem. Soc. 129 (2007) 13392.

159 L. Wang, W. Zhao, M. B. O’Donoghue and W. Tan: Bioconjug. Chem. 18 (2007) 297.

160 H. W. Gu, K. Xu, C. Xu and B. Xu: Chem. Commun. 9 (2006) 941.

161 J. Gao, L. Li, P. L. Ho, G. C. Mak, H. Gu and B. Xu: Adv. Mater. 18 (2006) 3145.

162 H. Yang, L. W. Qu, Y. Lin, X. P. Jiang and Y. P. Sun: J. Biomed. Nanotechnol. 3 (2007) 131.

163 C. W. Donnelly: Nutr. Rev. 59 (2001) 183.

164 W. Lian, S. A. Litherland, H. Badrane, W. Tan, D. Wu, H. V. Baker, P. A. Gulig, D. V. Lim and S. Jin: Anal. Biochem. 334 (2004) 135.

165 C. S. Chen, A. J. Baeumner and R. A. Durst: Talanta 67 (2005) 205.

166 L. Y. Lee, S. L. Ong, J. Y. Hu, W. J. Ng, Y. Feng, X. Tan and S. W. Wong: Appl. Environ. Microbiol. 70 (2004) 5732.

167 H. C. Chang: AIChe. J. 53 (2007) 2486.

168 Y. Lin, X. P. Jiang, T. Elkin, K. A. S. Fernando, L. R. Gu, S. Taylor, H. Yang, E. Jones, W. Wang and Y. P. Sun: J. Nanosci. Nanotechnol. 6 (2006) 868.

169 H. Yang, L. W. Qu, A. N. Wimbrow, X. P. Jiang and Y. P. Sun: Int. J. Food Microbiol. 118 (2007) 132.

170 R. A. N. Chmielewski and J. F. Frank: Compr. Rev. Food Sci. Food Saf. 2 (2003) 22.

171 J. F. Frank and R. A. Koffi: J. Food Prot. 53 (1990) 550.

172 M. Bruchez, M. Moronne, P. Gin, S. Weiss and A. P. Alivisatos: Science 281 (1998) 2013.

173 L. Yang and Y. Li: Analyst 131 (2006) 394.

174 C. S. Chen and R. A. Durst: Talanta 69 (2006) 232.

175 R. Beckman, E. Johnston-Halperin, Y. Luo, J. E. Green and J. R. Heath: Science 310 (2005) 465. 